\title{
The Vertical Distribution of Marine Macroplankton. An Observation on Diurnal Changes.
}

\author{
By \\ F. S. Russell, D.S.C., B.A., \\ Assistant Naturalist at the Plymouth Laboratory.
}

With 1 Plate and 6 Figures in the Text.

\section{INTRODUCTION.}

WHILE many collections have been made on oceanographical expeditions to study the vertical distribution of organisms in deep waters, few observations have been made on the vertical distribution of the larger marine plankton animals in coastal waters. This is possibly in part due to their comparatively small numbers in a given volume of water as compared with the immense numbers of the more minute organisms, such as diatoms or even the smaller copepods, and hence the necessity for the filtration of a very large body of water in order to obtain significant figures ; in part also to the fact that owing to the large size of the net required to filter so great a body of water, the fishing depth has always been unknown.

The first difficulty has been overcome of late years by the introduction of the material known as "stramin," which on account of its cheapness and durability compared with silk makes large nets for everyday use a possibility. Its large mesh (ca. 16 strands to $1^{\prime \prime}$ ) causes the retention of only the more bulky of the plankton organisms.

The Admiralty authorities have very kindly lent us an instrument which records graphically the depths at which a net has fished during the whole of its period under water: with this assistance the second hindrance is removed, and we can say with certainty the depths from which the plankton has been taken.

Researches were carried out primarily to study the vertical distribution of the larval and post-larval stages of our food fishes; the necessity of an understanding, not only of the vertical distribution of these stages but of their occurrence in relation to other living organisms of their environment, including both their food and their enemies, has naturally led to a more intensive study of the distribution of zooplankton as a whole.

The majority of observations up to date have been made in the daytime; but it is necessary to know also the distribution at night and the 
successive changes that take place to bring about the well-known diurnal variations in vertical distribution. For this purpose a series of hauls was taken on July 15-16, 1924, and it is with these alone that this paper deals.

\section{Method of Collecting.}

The net used was a ring trawl with an opening of 2 metres diameter ; it was made of stramin, and was 6 metres in length. A short account of the method of working this net has been given elsewhere (Russell, 14).

The locality chosen was the hydrographical Station L4, midway between the Plymouth Breakwater and the Eddystone Lighthouse. Here there is a depth of 28 fathoms ( 51 metres), and the bottom for some distance round is level. This position is sufficiently far from the coast line to avoid the local swirls and upward currents, which are the constant normal events of waters close inshore, and which might be strong enough to prevent the larger plankton animals from assuming their typical vertical distribution of more open waters: that vertical mixing does occur however in this region, especially during rough weather, is shown by temperature (Harvey, 6) and phosphate determinations (Atkins, 1). Results of day collecting also have shown that the inshore distribution is markedly different from that at L4, in that the upper layers are as rich in plankton as the deeper. For instance, on June 27th, 1924, about two miles from the coast over a depth of 45 metres the following quantities of plankton were caught in a metre closing net towed horizontally :-

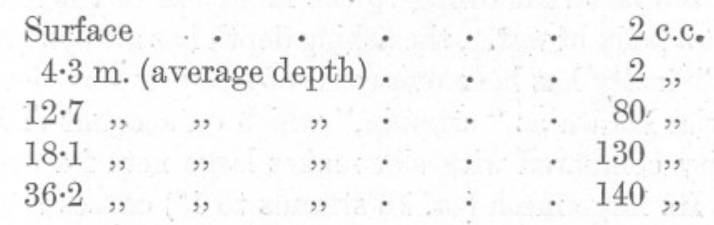

Whereas on the same day with the same gear, close inshore over a depth of 15 metres, the following results were obtained :-

\begin{tabular}{|c|c|c|}
\hline Surface & & \\
\hline $4 \cdot 3 \mathrm{~m}$. & & \\
\hline $9 \cdot 6$, & . & \\
\hline
\end{tabular}

This is probably to be accounted for by increased turbidity as well as by mixing.

Herdman and Scott (8) also remark that " the surface plankton is often more abundant in the bay than at the offshore stations."

It was decided to collect samples from five different depths. To obtain ideal results five nets would be required to fish simultaneously at the five given depths, a depth-recorder would have to be attached to each net, and each net would have to possess an efficient opening and olosing 

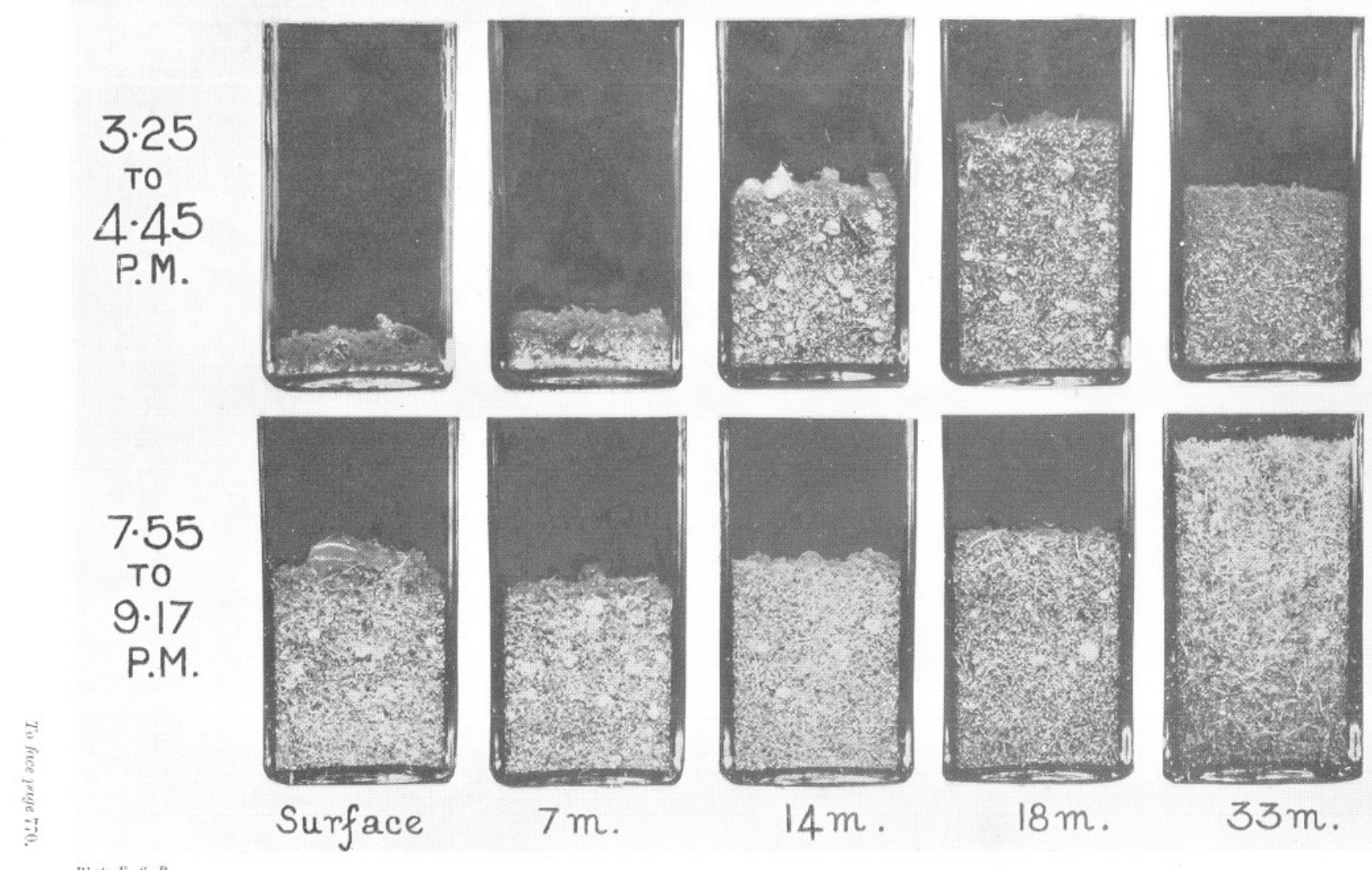

DAYLIGHT
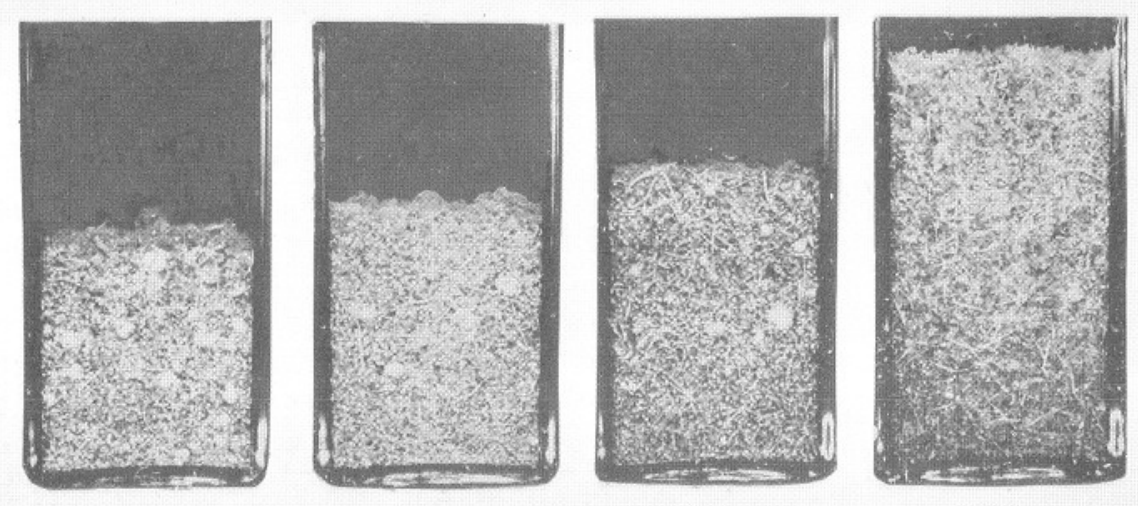

DUSK

$7 m$.

$14 \mathrm{~m}$.

$18 \mathrm{~m}$.

$33 m$.

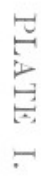

Photograph of the actual catches of plankton made by the ring-trawl at five depths in daylight and at dusk, showing how the upper layers had little plankton in daylight and at dusk they had become thickly populated. 
Table 1.

Date: July 15-16th, 1924.

Position: L 4 .

Ship: S.S. "Salpa."

Gear : 2 metre ring-trawl.

\begin{tabular}{|c|c|c|c|c|c|c|}
\hline & Depth. & $\begin{array}{c}\text { Time net } \\
\text { entered water. }\end{array}$ & Fishing time. & $\begin{array}{l}\text { Time net } \\
\text { left water. }\end{array}$ & $\begin{array}{l}\text { Length of } \\
\text { warp out. }\end{array}$ & Notes. \\
\hline $\begin{array}{l}\text { 1st Series : } \\
\text { Sun shining: sea } \\
\text { calm : no wind }\end{array}$ & $\begin{array}{c}\text { V } \\
\text { IV } \\
\text { III } \\
\text { II } \\
\text { Surface }\end{array}$ & $\begin{array}{l}3.23 \frac{1}{2} \text { p.m. } \\
3.42 \frac{1}{2} \quad, \\
4 \quad ", \\
4.18 \quad,\end{array}$ & $\begin{array}{l}3.25-3.35 \text { p.m. } \\
3.44-3.55 \quad ", \\
4.1-4.11 \quad ", \\
4.18 \frac{1}{4} 4.28 \frac{1}{4}, " \\
4.34-4.44 \frac{1}{2} \quad "\end{array}$ & \begin{tabular}{l}
$3.37 \mathrm{p} . \mathrm{m}$ \\
$3.55 \frac{1}{2} \quad$, \\
$4.12 \quad$, \\
$4.28 \frac{1}{2} \quad$, \\
\multicolumn{2}{l}{}
\end{tabular} & $\begin{array}{l}50 \text { fathoms } \\
30 \quad, \\
20 \quad \text { ", } \\
10 \quad \text { " }\end{array}$ & $\begin{array}{l}- \\
- \\
-\end{array}$ \\
\hline $\begin{array}{l}\text { 2nd Series : } \\
\text { Sunset, } 8.3 \text { p.m. } \\
\text { Clouding over : sea } \\
\text { calm : no wind }\end{array}$ & $\begin{array}{c}\text { V } \\
\text { IV } \\
\text { III } \\
\text { II } \\
\text { Surface }\end{array}$ & \begin{tabular}{l}
7.54 p.m. \\
$8.14 \quad$, \\
$8.31 \frac{1}{2} \quad "$, \\
$8.49 \quad "$ \\
\multicolumn{2}{c}{$\quad$}
\end{tabular} & $\begin{array}{l}7.55 \frac{3}{4} 8.6 \text { p.m. } \\
8.15-8.25 \quad, \\
8.32 \frac{1}{2}-8.42 \frac{1}{2}, \\
8.49 \frac{1}{2}-8.59 \frac{1}{2}, \\
9.7 \frac{1}{2}-9.17 \frac{1}{2} \quad,\end{array}$ & $\begin{array}{l}8.8 \text { p.m. } \\
8 \cdot 26, " \\
8.43 \frac{1}{4}, \\
9 \quad, \\
\quad=\end{array}$ & $\mid \begin{array}{l}50 \text { fathoms } \\
30 \quad, \\
20 \quad, \\
10 \quad, \\
-\end{array}$ & $\begin{array}{l}-\frac{-}{-} \\
\text { Getting difficult to see. } \\
\text { Lights necessary for reading.' }\end{array}$ \\
\hline $\begin{array}{l}\text { 3rd Series : } \\
\text { Full moon rose at } \\
9.40 \text { p.m. : coming up } \\
\text { from bank of clouds } \\
\text { into clear sky with } \\
\text { occasional flaky clouds }\end{array}$ & $\begin{array}{l}\text { V } \\
\text { IV } \\
\text { III } \\
\text { II } \\
\text { Surface }\end{array}$ & $\begin{array}{l}10.50 \text { p.m. } \\
11.15 \quad, \\
11.33 \frac{1}{2}, \\
11.51 \frac{1}{2},\end{array}$ & $\begin{array}{c}10.52-11.3 \frac{1}{2}^{*} \mathrm{p} . \mathrm{m} . \\
11.16-11.26, " \\
11.34-11.44 \frac{1}{2}, " \\
11.52 \text { p.m. }-12.2 \frac{1}{2} \mathrm{a} . \mathrm{m} . \\
12.9 \frac{1}{2}-12.19 \frac{1}{2}, "\end{array}$ & $\begin{array}{l}11.6 \text { p.m. } \\
11.27 \frac{1}{2}, \\
11.45 \frac{1}{2}, \\
12.3 \mathrm{a.m} . \\
\quad-\end{array}$ & $\mid \begin{array}{ll}50 & \text { fathoms } \\
30 & , \\
20 & , \\
10 & ,\end{array}$ & $\begin{array}{l}\text { Moon behind thin cloud. } \\
\text { Moon quite hidden by clouds. } \\
\text { Small clouds passing over moon } \\
\text { Small clouds passing over moon } \\
\text { Moon hidden: raining at } 12.18 \\
\text { a.m. }\end{array}$ \\
\hline $\begin{array}{l}\text { 4th Series : } \\
\quad \text { Wind freshening: } \\
\text { Sea loppy : }\end{array}$ & $\begin{array}{l}\text { V } \\
\text { IV } \\
\text { III }\end{array}$ & $\begin{array}{l}2.50 \frac{1}{2} \text { a.m. } \\
3.13 \frac{1}{4} \quad, \\
3.33 \frac{1}{4} \quad,\end{array}$ & $\begin{array}{lc}2.52-3.2 & \text { a.m. } \\
3.14 \frac{1}{4}-3.25 & \quad, \\
3.34-3.44 \frac{1}{2} & \quad,\end{array}$ & $\begin{array}{l}3.4 \frac{1}{2} \quad \text { a.m. } \\
3.26 \frac{1}{2} \quad, \quad \\
3.45 \frac{1}{4} \quad,\end{array}$ & $\begin{array}{l}50 \text { fathoms } \\
30 \quad, \\
20 \quad,\end{array}$ & $\begin{array}{l}\text { Clouded : grey-dark. } \\
\text { Getting light. } \\
\text { Deck light out : could just see } \\
\text { to read. }\end{array}$ \\
\hline Raining & $\begin{array}{c}\text { II } \\
\text { Surface }\end{array}$ & $3 \cdot 51$ & $\begin{array}{l}3.51 \frac{1}{4}-4.1 \frac{1}{4} \quad, \\
4.6 \frac{1}{4}-4.16 \frac{1}{4} \quad,\end{array}$ & $4.1 \frac{3}{4}+$ & $10 \quad$, & - \\
\hline $\begin{array}{l}\text { 5th Series : } \\
\text { Sun shining: } \\
\text { Sea slightly } \\
\text { "loppy", }\end{array}$ & $\begin{array}{l}\text { V } \\
\text { IV } \\
\text { III } \\
\text { II } \\
\text { Surface }\end{array}$ & $\begin{array}{l}8.45 \text { a.m. } \\
9.6 \frac{3}{4} \quad, \\
9.25 \frac{1}{2} \quad " \\
9.42 \frac{1}{2} \quad, \\
\quad-\end{array}$ & $\begin{array}{ll}8.46 \frac{1}{2}-8.56 \frac{1}{2} & \text { a.m. } \\
9.7 \frac{3}{4}-9.17 \frac{3}{4} & , \\
9.26-9.36 & , \\
9.43-9.53 & " \\
10-10.11 & "\end{array}$ & $\begin{array}{l}8.59 \text { a.m. } \\
9.19 \quad ", \\
9.36 \frac{3}{4} \quad ", \\
9.53 \frac{3}{4} \quad "\end{array}$ & $\mid \begin{array}{l}50 \text { fathoms } \\
30 \quad, \\
20 \quad ", \\
10 \quad \text { " }\end{array}$ & Sun clouded. \\
\hline
\end{tabular}

* The numbers of all organisms caught in this haul, which was $11 \frac{1}{2}$ min., have been corrected for ten minutes. 
Minutes.
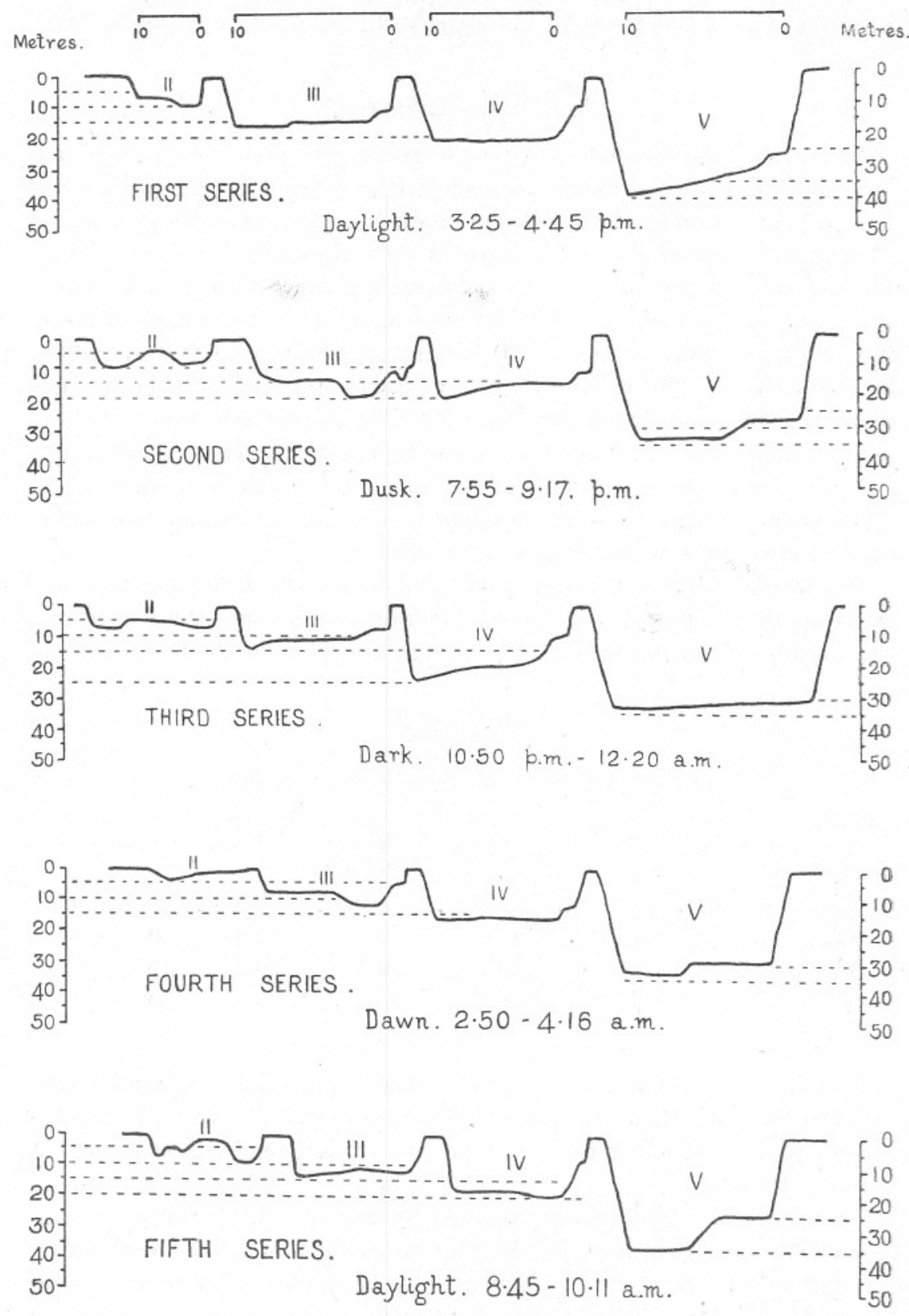

Figure 1. The five series of curves given by the depth-recorder indicating the path of the net through the water at the four depths II,.HI, IV, and V. (The surface haul is not included.) The net enters the water on the right-hand side of each curve. (The differences in the lengths of the curves are due to irregularities in the speed of the recorder cloek and not to errors in timing.) 
The catches were preserved immediately the net came aboard by the addition of sufficient formalin to bring the solution to a strength of $5 \%$.

\section{The Depth Records.}

Tracings of the results shown by the graphic depth-recorder are given in Fig. 1. Each series should be read from right to left, and starts with the curve produced by the net at the depth No. V, that is with 50 fathoms of wire out. For the sake of clearness we will describe the first series. The net entered the water at the right end and immediately sank as the warp was paid out to a depth of 26 metres, at which it fished for a short time then gradually sinking to 40 metres, at which point it was hauled to the surface. The clockwork drum was then stopped until the net was ready for the next haul at depth No. IV; in this haul the net fished steadily at a depth of 20 metres, until it was again hauled to the surface. In each series a record of the surface haul tracing has been omitted as this was unnecessary; the net was kept in such a position that the upper edge of the ring was just beneath the surface.

The average depth at which each haul was made has been deduced by measuring the depths at ten equidistant points along the respective curves and taking the mean. The results are given in Table 2.

\section{TABLE 2 .}

\begin{tabular}{|c|c|c|c|c|c|c|}
\hline & AVE & DEPTH & in Metres & FOR $\mathrm{F}$ & H $\mathrm{HA}_{\mathrm{A}}$ & \\
\hline Depth. & $\begin{array}{l}\text { lst } \\
\text { Series. }\end{array}$ & $\begin{array}{l}\text { 2nd } \\
\text { Series. }\end{array}$ & $\begin{array}{c}\text { 3rd } \\
\text { Series. }\end{array}$ & $\begin{array}{l}\text { 4th } \\
\text { Series. }\end{array}$ & $\begin{array}{l}\text { 5th } \\
\text { Series. }\end{array}$ & $\begin{array}{l}\text { Length of } \\
\text { warp. }\end{array}$ \\
\hline $\operatorname{urfac}$ & - & - & - & - & - & - \\
\hline II & $6.6 \mathrm{~m}$. & $7 \mathrm{~m}$ & $5 \cdot 8 \mathrm{~m}$. & $1.9 \mathrm{~m}$. & $5 \cdot 3 \mathrm{~m}$. & 10 fathon \\
\hline III & $13 \cdot 6$, & $15 \cdot 1$, & $11 \cdot 2$ & & 12.5, & 20 \\
\hline IV & 5, & $17 \cdot 1$, & $20 \cdot 7$, & 16 & 18.3, & 30 \\
\hline $\mathrm{V}$ & $34 \cdot 5$, & $32 \cdot 3$, & $32 \cdot 2$, & $30 \cdot 1$, & $31 \cdot 1$, & 50 \\
\hline
\end{tabular}

It is interesting to note in Table 2 that the average depths for the hauls in the 4 th series are all less than in any other. This is probably correlated with the fact that the wind was freshening at this time, as noted in the log.

On the whole, the levels maintained by the net on this occasion are remarkably good; in fact, probably quite as good as could be expected through such a large series of hauls. This is fortunate, as it brings the depths II, III, IV, and V very nearly the same in each series, and so helps comparison in distribution of the organisms caught. 
TABLE 3 .

Showing Complete Count of the Organisms in the Surface Haul of No. II Series, obtained by making up to 5 Litres and taking 10 Samples Each of 500 C.C.

\begin{tabular}{|c|c|c|c|c|c|c|c|c|c|c|c|c|c|c|c|c|c|c|c|}
\hline Sample No. & 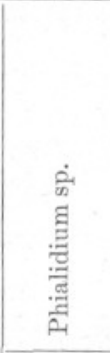 & 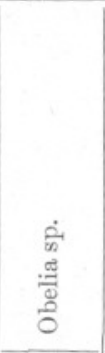 & 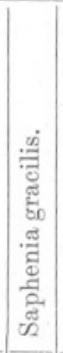 & 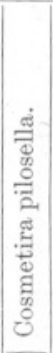 & 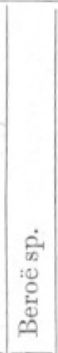 & 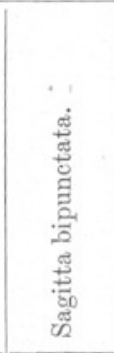 & 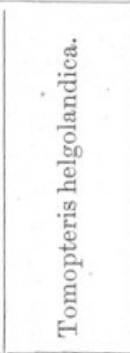 & 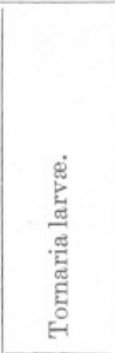 & 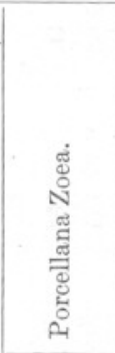 & 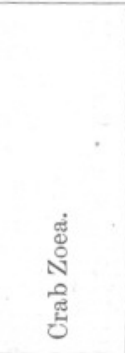 & 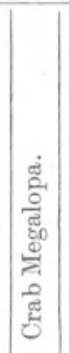 & 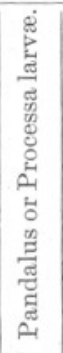 & 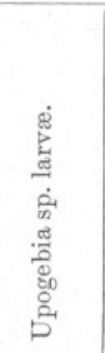 & 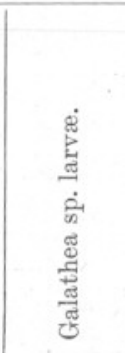 & 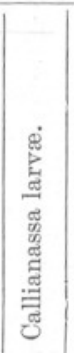 & 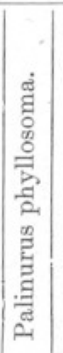 & 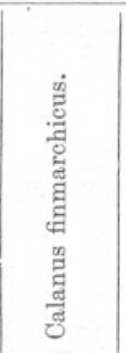 & 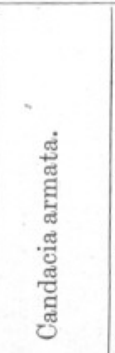 & 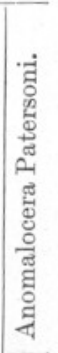 \\
\hline $\begin{array}{r}1 . \\
2 . \\
3 . \\
4 . \\
5 . \\
6 . \\
7 . \\
8 . \\
9 . \\
10 .\end{array}$ & $\begin{array}{l}214 \\
246 \\
203 \\
255 \\
234 \\
241 \\
254 \\
231 \\
247 \\
205\end{array}$ & $\begin{array}{l}17 \\
15 \\
15 \\
20 \\
28 \\
19 \\
14 \\
20 \\
11 \\
11\end{array}$ & $\begin{array}{l}5 \\
0 \\
1 \\
3 \\
2 \\
4 \\
2 \\
2 \\
3 \\
4\end{array}$ & $\begin{array}{l}1 \\
1 \\
4 \\
2 \\
2 \\
0 \\
3 \\
4 \\
0 \\
2\end{array}$ & $\begin{array}{r}6 \\
6 \\
11 \\
8 \\
2 \\
11 \\
4 \\
7 \\
8 \\
6\end{array}$ & $\begin{array}{l}203 \\
189 \\
194 \\
208 \\
189 \\
223 \\
254 \\
204 \\
204 \\
192\end{array}$ & $\begin{array}{l}56 \\
54 \\
57 \\
63 \\
57 \\
53 \\
83 \\
52 \\
55 \\
51\end{array}$ & $\begin{array}{r}107 \\
119 \\
101 \\
105 \\
127 \\
99 \\
147 \\
129 \\
101 \\
118\end{array}$ & $\begin{array}{l}337 \\
313 \\
314 \\
327 \\
387 \\
415 \\
435 \\
371 \\
275 \\
324\end{array}$ & $\begin{array}{l}277 \\
267 \\
290 \\
375 \\
323 \\
380 \\
413 \\
315 \\
265 \\
303\end{array}$ & $\begin{array}{l}1 \\
0 \\
6 \\
4 \\
3 \\
2 \\
5 \\
5 \\
3 \\
5\end{array}$ & $\begin{array}{l}2 \\
0 \\
0 \\
2 \\
1 \\
1 \\
3 \\
1 \\
1 \\
2\end{array}$ & $\begin{array}{l}47 \\
72 \\
70 \\
61 \\
61 \\
97 \\
86 \\
58 \\
52 \\
59\end{array}$ & $\begin{array}{l}19 \\
20 \\
19 \\
22 \\
22 \\
25 \\
28 \\
21 \\
17 \\
18\end{array}$ & $\begin{array}{r}4 \\
8 \\
6 \\
16 \\
11 \\
16 \\
17 \\
16 \\
7 \\
11\end{array}$ & $\begin{array}{l}1 \\
0 \\
1 \\
4 \\
3 \\
2 \\
2 \\
1 \\
2 \\
2\end{array}$ & $\begin{array}{l}422 \\
339 \\
421 \\
446 \\
457 \\
643 \\
708 \\
451 \\
438 \\
489\end{array}$ & $\begin{array}{l}58 \\
47 \\
56 \\
61 \\
48 \\
70 \\
68 \\
64 \\
48 \\
52\end{array}$ & $\begin{array}{l}4 \\
1 \\
2 \\
4 \\
3 \\
1 \\
4 \\
2 \\
2 \\
2\end{array}$ \\
\hline \begin{tabular}{l}
\multicolumn{1}{c}{ Total } \\
Mean \\
Standard* \\
deviation \\
Probable \\
Error
\end{tabular} & $\begin{array}{c}2330 \\
233 \\
\\
\pm 18 \cdot 4 \\
\pm 12 \cdot 4 \\
\text { or } \\
\pm \mathbf{5} \cdot 3 \%\end{array}$ & $\begin{array}{c}170 \\
17 \\
\pm 4 \cdot 8 \\
\pm 3 \cdot 2 \\
\text { or } \\
\pm: 19 \%\end{array}$ & $\mid \begin{array}{l}26 \\
2 \cdot 6 \\
- \\
- \\
-\end{array}$ & $\begin{array}{l}19 \\
1 \cdot 9 \\
- \\
- \\
-\end{array}$ & $\begin{array}{l}69 \\
6 \cdot 9 \\
- \\
- \\
-\end{array}$ & $\begin{array}{c}2060 \\
206 \\
\pm 18 \cdot 8 \\
\pm 12 \cdot 7 \\
\text { or } \\
\pm 6 \cdot 2 \%\end{array}$ & $\begin{array}{c}581 \\
58 \cdot 1 \\
\pm 8 \cdot 9 \\
\pm 6 \\
\stackrel{\text { or }}{ } \\
\pm \mathbf{1 0 \cdot 4} \%\end{array}$ & $\begin{array}{c}1153 \\
115 \cdot 3 \\
\pm 14 \cdot 8 \\
\pm 10 \\
\text { or } \\
\pm 8 \cdot \% \%\end{array}$ & $\begin{array}{c}3498 \\
349 \cdot 8 \\
\pm 47 \cdot 9 \\
\pm 32 \cdot 3 \\
\text { or } \\
\pm 9 \cdot 2 \%\end{array}$ & $\begin{array}{l}3208 \\
320 \cdot 8 \\
\\
\pm 49 \cdot 2 \\
\pm 33 \cdot 2 \\
\quad \text { or } \\
\pm \mathbf{1 0} \cdot 4 \%\end{array}$ & $\begin{array}{l}34 \\
3 \cdot 4 \\
- \\
- \\
-\end{array}$ & $\begin{array}{c}13 \\
1 \cdot 3 \\
- \\
- \\
- \\
-\end{array}$ & $\begin{array}{l}663 \\
66 \cdot 3 \\
\pm \overline{14} \cdot 6 \\
\pm 9 \cdot 9 \\
\text { or } \\
\pm 15 \%\end{array}$ & $\begin{array}{c}211 \\
21 \cdot 1 \\
\pm 3 \cdot 5 \\
\pm 2 \cdot 4 \\
\text { or } \\
\pm 11 \cdot 4 \%\end{array}$ & $\begin{array}{c}112 \\
11 \cdot 2 \\
- \\
- \\
-\end{array}$ & $\begin{array}{c}18 \\
1 \cdot 8 \\
- \\
- \\
-\end{array}$ & $\begin{array}{c}4814 \\
481 \cdot 4 \\
\pm 103 \cdot 2 \\
\pm 69 \cdot 5 \\
\text { or } \\
\pm 14.5 \%\end{array}$ & $\begin{array}{l}572 \\
57 \cdot 2 \\
\pm 8 \\
\pm 5 \cdot 4 \\
\text { or } \\
\pm \mathbf{9} \cdot \mathbf{5} \%\end{array}$ & $\begin{array}{l}25 \\
2 \cdot 5 \\
- \\
-\end{array}$ \\
\hline
\end{tabular}

* The standard deviation was obtained from the formula S.D. or $\sigma=\sqrt{\frac{\Sigma\left(\mathrm{d}^{2}\right)}{\mathrm{n}}}$ where $\sigma=$ standard deviation. d $=$ the deviation from the arithmetic average, $\mathrm{n}=$ the number of samples. The Probable Error is $0.6745 \sigma$. 


\section{Examination of Material.}

At first an attempt was made to analyse the catches by making a complete count of each: when the first large catch was encountered, however, it took 10 days to exhaust, and it was therefore necessary to find some method of sampling.

The method adopted was to place the catch in a large open-mouthed bell-jar with a diameter of 12 inches : this was then made up to 5 litres. A 500 c.c. sample, $\frac{1}{10}$ th of the whole catch, was extracted by using a finger-bowl as a dipper. The organisms were thoroughly mixed until their distribution appeared as even as possible and a rapid dip made, care being taken to scoop right to the bottom in order to sample any organisms that sank quickly. One dip would take up about 100 c.c.;

\section{TABLE 4.}

Volumes of each Catch in Cubic Centimetres after Settling FOR 24 Hours.

\begin{tabular}{|c|c|c|c|c|c|}
\hline Depth. & Ist Series. & 2nd Series. & 3rd Series. & 4th Series. & 5th Series. \\
\hline $\begin{array}{c}\text { Surface } \\
\text { II }\end{array}$ & $\begin{array}{l}25 \text { c.c. } \\
50\end{array}$ & $\begin{array}{l}225 \text { c.c. } \\
220\end{array}$ & $\begin{array}{l}340 \text { c.c. } \\
145\end{array}$ & $\begin{array}{l}205 \text { c.c. } \\
200\end{array}$ & $\begin{array}{l}75 \text { c.c. } \\
150\end{array}$ \\
\hline III & 220 & 250 & $1=0$ & 230 & 335 \\
\hline IV & 315, & 300 & $150 \%$ & 205 & 440 \\
\hline V & 195, & 420, & 340, & 250, & 260, \\
\hline
\end{tabular}

the operation was repeated 5 or 6 times until the complete 500 c.c. had been extracted, the whole being well stirred up between each dip. Taking 5 or 6 dips for each sample probably tended to increase the accuracy of the method, by smoothing over errors caused by organisms clinging together in clumps, although great care was taken to see that the various animals were separated from one another as much as possible.

For one bottle, the surface haul of the 2nd series, 10 such samples were taken, and thus a complete count was made. The results are set out in Table 3, and in view of the various sizes and shapes of the organisms in question the method is probably as good as can be found. On no occasion in which the average number of any one species in a sample was over 20 was the probable error greater than $15 \%$. If there were less than 20 individuals of a species in a sample no importance could be attached to the actual figure, but at any rate it is a proof that the organism was not very abundant.

Before each catch was made up to 5000 c.c. a complete count was made of certain organisms that were easy to pick out on account of their 
size or their colour, such as various mysids; Turris pileata, Anomalocera patersoni, Themisto gracilipes.

Those with any distinctive colour could be very quickly observed by placing the plankton in a shallow tray over a white ground for coloured animals and a black ground for white forms.

Also each catch was placed in a large measuring cylinder, and allowed to settle for 24 hours. The settled volume was then read off in cubic centimetres. The results are set out in Table 4. The actual catches in the first two series were photographed, and Plate I gives a very graphic impression of how the two upper layers were filled up at dusk.

For the identification of the various species my thanks are especially due to Dr. M. V. Lebour for the great assistance she has given me, to Mr. E. T. Browne for confirmation of the various Medusæ, and to Mr. R. Gurney for his assistance with the Decapod larvæ. My thanks are also due to Dr. E. J. Allen, F.R.s., and other members of the staff for their kind advice on many points.

\section{Results.}

In considering the results shown by the numbers obtained, three points must be borne in mind that tend to obscure the true picture of events.

1. The net was not fitted with a closing apparatus : in Table 1 we can see the time required to shoot and haul the net at each successive depth. This time naturally increases for the deeper hauls. The time of shooting for the deepest hauls is from $1 \frac{1}{2}$ to 2 minutes, the time of hauling 2 to $2 \frac{1}{2}$ minutes. While shooting the net will be fishing to a certain extent, though the catch would probably be very small as the net is moving only a very slight distance through the water or is almost stationary, the ship leaving it behind as the warp runs off the winch; when hauling, however, the net is fishing efficiently for 2 to $2 \frac{1}{2}$ minutes over and above the scheduled 10 minutes. Whereas in the daytime this will not cause a very great error, because for half this time the net will be passing through the upper layers where there is little plankton; at night the error will be greater when the layers from top to bottom become filled with plankton.

No attempt has been made to correct for this ; it would be too complicated on account of the different numbers met with at different levels.

2. As mentioned before each haul is taken in succession, and the net in one series, therefore, takes samples from five different bodies of water. This may cause misleading results if at any time during the series the ship passes into a region either more or less populated. There do not, however, appear to be many signs of this ; when forms were encountered in large numbers in any one haul they were present in correspondingly 
large numbers in the remaining samples of the series, and similarly they might be proportionately scarce right through the layers.

For instance, the two series of day hauls for the zoea of Porcellana sp. (p. 803), although showing very different totals when the five catches of each series are added together, nevertheless show remarkably similar proportionate distribution.

It is highly probable that when animals of the size taken in the ringtrawl are present in swarms that they are distributed over a very large area, in a manner very different from the possible compact little swarms of the smaller copepods.

\section{TABLE 5 .}

\section{Total Numbers of Organisms in each Catch.}

\begin{tabular}{|c|c|c|c|c|c|}
\hline & $\begin{array}{l}\text { 1st Series. } \\
3.25 \text { p.m. to } \\
4.45 \text { p.m. }\end{array}$ & $\begin{array}{l}\text { 2nd Series. } \\
7.55 \text { p.m. to } \\
9.17 \text { p.m. }\end{array}$ & $\begin{array}{l}\text { 3rd Series. } \\
10.50 \text { p.m. to } \\
12.20 \text { a.m. }\end{array}$ & $\begin{array}{l}\text { 4th Series. } \\
2.50 \text { a.m. to } \\
4.16 \text { a.m. }\end{array}$ & $\begin{array}{l}5 \text { th Series. } \\
8.45 \text { a.m. to } \\
10.11 \text { a.m. }\end{array}$ \\
\hline Surface & $\begin{array}{l}958 \\
1 \cdot 1 \%\end{array}$ & $\begin{array}{l}19,851 \\
15 \cdot 2 \%\end{array}$ & $\begin{array}{l}28,487 \\
2 \% \cdot 4 \%\end{array}$ & $\begin{array}{l}1709 \\
2.9 \%\end{array}$ & $\begin{array}{l}3291 \\
2 \cdot 6 \%\end{array}$ \\
\hline II & 3408 & 20,774 & 13,043 & 5380 & 8403 \\
\hline $2-7 \mathrm{~m}$ & $3.8 \%$ & $15.9 \%$ & $12.5 \%$ & $9 \%$ & $6 \cdot 6 \%$ \\
\hline III & 17,458 & 21,968 & 11,754 & 18,401 & 35,659 \\
\hline $9-15 \mathrm{~m}$. & $19.5 \%$ & $16.9 \%$ & $11 \cdot 4 \%$ & $30.9 \%$ & $28.3 \%$ \\
\hline IV & 27,828 & 25,223 & 14,546 & 15,859 & 51,535 \\
\hline $16-20 \mathrm{~m}$. & $31 \cdot 1 \%$ & $19 \cdot 4 \%$ & $14 \cdot 1 \%$ & $26 \cdot 6 \%$ & $40 \cdot 7 \%$ \\
\hline V & 39,818 & 42,399 & 36,384 & 18,218 & 27,454 \\
\hline $30-34 \mathrm{~m}$. & $44.5 \%$ & $32 \cdot 6 \%$ & $35 \%$ & $30 \cdot 6 \%$ & $21 \cdot 8 \%$ \\
\hline Total & $\begin{array}{l}89,470 \\
100 \%\end{array}$ & $\begin{array}{c}130,215 \\
100 \%\end{array}$ & $\begin{array}{c}104,214 \\
100 \%\end{array}$ & $\begin{array}{l}59,567 \\
100 \%\end{array}$ & $\begin{array}{c}126,342 \\
100 \%\end{array}$ \\
\hline
\end{tabular}

3. There are errors due to the method of sampling, but these are considered to be insufficient to affect the signficance of the figures obtained.

Further, this is only one observation in one region on a single night in the year, and there is, therefore, no justification in attempting to draw conclusions as to the normal behaviour of any organism from the results obtained.

This is only a contribution to the many similar observations that must be made before we can understand the regular habits of the animals in question. There are so many factors making up the environment that it is necessary to have observations taken under all conditions. In this case collecting took place during a period of full moon, and it is highly possible that on dark moonless nights the animals' behaviour might be different. Also there is the time of year to be considered, the summer 
distribution probably being very dissimilar from that in winter. Herdman and Scott ( are repeatedly remarking on the occurrence of large numbers of forms on the surface up to mid April that have their position of maximum abundance in the daytime at a depth of a few fathoms in summer, and my collections are showing the same results.

Table 5 gives the total numbers of organisms taken in each haul, and shows how the two upper layers have been filled up between 9 p.m. and midnight. Also it corrects the idea given by the settled volumes showing that by $4 \mathrm{a}$.m. most of the organisms have left the surface, the high volume being caused by large numbers of Turris.

Altogether some fifty different organisms occurred in this collection, and it is, of course, the sum of the various movements of each kind of animal that gives rise to the figures quoted in Table 5 .

On this occasion the various distributions of the different species throughout the five series show that all the animals in question did not behave in the same manner. The reactions to the various environmental changes that occur in the passage from daylight to daylight shown by the animals captured on this occasion can be grouped under four headings.

1. Those that definitely migrated to the surface at night from the deeper layers in which they dwelt by day, showing a very large increase in numbers on the surface with a corresponding decrease in the deeper layers (Figure 2).

Some forms that exhibited this reaction were :-

Calanus finmarchicus, Turris pileata, Tornaria larvae, Upogebia larvae, Callianassa subterranea larvæ, Themisto gracitipes, possibly Tomopteris, Urothoë sp.

2. Those that did not show a definite migration to the surface at night, but merely extended their distribution into the surface layers, which they avoided by day. In this case a diminution in numbers was shown at the region of maximum intensity in daytime, so that the distribution from surface to deeper layers was more or less uniform.

Such a reaction was exhibited by :-

Porcellana zoea, Crab zoea, and Sagitta bipunctata (Figure 3).

3. Those forms whose daytime distribution altered little or not at all at night (Figure 4). These were :-

Pandalus larvæ, Galatheid larvæ, Pagurid larvæ, Phialidium sp., Obelia sp., Apherusa sp., Larval molluscs.

4. Those that showed a movement upwards from the bottom, appearing in large numbers at night at a level about 10 fathoms from the bottom. 
These were mostly benthic forms, which probably live normally in the daytime, actually crawling on the bottom, e.g. Amphipods, burrowing e.g. Cumacea, or free swimming in the water layers immediately adjacent to the bottom, e.g. Mysids and also the later stages of the young of various decapods that are living near the bottom preparatory to taking up their permanent habitat there by day when they have reached their adult stages (Figure 5).

These were :-

Leptomysis gracilis, Haplostylus Normani, Schistomysis sp., Dasymysis sp., Crangonid post-larvæ, Galatheid post-larvæ, Upogebia sp. postlarvæ, Eupagurus sp. Glaucothoë, Diastylis sp., Cumacea (indet).

In the following list all the animals present in the collections are grouped under their respective types of behaviour. An asterisk (*) denotes that the species in question was present only in small numbers, which were regarded as insufficient to be conclusive, though showing a tendency towards a definite behaviour. (c) signifies that a complete count was made of the animal in question; figures for the remaining species were obtained by sampling.

DEFINITE MIGRATION TO SURFACE.

Stomotoca dinema*. (c.)

Turris pileata. (c.)

Cosmetira pilosella*. (c.)

Tomopteris helgolandica. (?)

Calanus finmarchicus.

Candacia armata.
Anchialus agilis. (c.)

Themisto gracilipes. (c.)

Urothoë sp. (c.)

Callianassa larvæ.

Upogebia ",

Tornaria ,

\section{EXTENSION OF DISTRIBUTION INTO UPPER LAYERS.}

Saphenia gracilis*. (c.)

Sagitta bipunctata.

Porcellana zoea.
Palinurus Phyllosoma. (c.)

Crab zoea.

Crab Megalopa.

LITTLE OR NO MOVEMENT.

Steenstrupia rubra.

Obelia sp.

Phialidium sp.

Aglantha rosea.

Peachia sp.

Pœcilochætus larvæ.

Anomalocera Patersoni. (c.)

Caligus sp. (c.)
Apherusa sp.

Leander sp. larvæ.

Pandalus ,

Processa ,,

Galatheid ,,

Pagurid ,

Limacina retroversa.

Larval gastropods. 
MOVEMENT UPWARDS FROM BOTTOM OR DEEP LAYERS.

Leptomysis gracilis. (c.)

Dasymysis longicornis. (c.)

Schistomysis sp. (c.)

Erythrops sp. (c.)

Haplostylus Normani. (c.)

Diastylis sp. (c.)
Cumacea (indet.). (c.)

Amphipoda ,, (c.)

Crangonid post-larvæ.

Galatheid ,

Upogebia ,,

Eupagurus Glaucothoë.

In the remaining pages the results for each organism are dealt with in detail.

\section{COELENTERATA.}

\section{ANTHOMEDUS压.}

Steenstrupia RUBra Forbes.

\begin{tabular}{|c|c|c|c|c|c|}
\hline & $\begin{array}{l}\text { 1st Series. } \\
3.25 \text { p.m. to } \\
4.45 \text { p.m. }\end{array}$ & $\begin{array}{l}\text { 2nd Series. } \\
7.55 \text { p.m. to } \\
9.17 \text { p.m. }\end{array}$ & $\begin{array}{l}\text { 3rd Series. } \\
10.50 \text { p.m. to } \\
12.20 \text { a.m. }\end{array}$ & $\begin{array}{l}\text { 4th Series. } \\
2.50 \text { a.m. to } \\
4.16 \text { a.m. }\end{array}$ & $\begin{array}{l}\text { 5th Series. } \\
8.45 \text { a.m. } \\
10.11 \text { a.m. }\end{array}$ \\
\hline Surface & - & - & - & - & - \\
\hline II $2.7 \mathrm{~m}$. & 一 & - & 一 & 一 & 一 \\
\hline III $9-15 \mathrm{~m}$. & 一 & 一 & 一 & - & 一 \\
\hline IV $16-20 \mathrm{~m}$. & 2 & 一 & 40 & 10 & 2 \\
\hline $\mathrm{V} \quad 30-34 \mathrm{~m}$. & 12 & 一 & 23 & 40 & 29 \\
\hline
\end{tabular}

This, the medusa of Corymorpha, was only taken in the deeper water layers in small numbers, and exhibited no marked vertical movements at night.

\section{Stomotoca dinema L. Agassiz.}

\begin{tabular}{|c|c|c|c|c|c|}
\hline & $\begin{array}{l}1 \text { st Series. } \\
25 \text { p.m. to } \\
4.45 \text { p.m. }\end{array}$ & $\begin{array}{l}\text { 2nd Series. } \\
7.55 \text { p.m. to } \\
9.17 \text { p.m. }\end{array}$ & $\begin{array}{l}\text { 3rd Series. } \\
10.50 \text { p.m. to } \\
12.20 \text { a.m. }\end{array}$ & $\begin{array}{l}4 \text { th Series. } \\
2.50 \text { a.m. to } \\
4.16 \text { a.m. }\end{array}$ & $\begin{array}{l}5 \text { th Series. } \\
8.45 \text { a.m. to } \\
10.11 \text { a.m. }\end{array}$ \\
\hline Surface & - & - & 22 & 1 & - \\
\hline II $2-7 \mathrm{~m}$. & 2 & - & 2 & 10 & 4 \\
\hline III 9-15 m. & 29 & - & 1 & 9 & 3 \\
\hline IV $16-20 \mathrm{~m}$ & . 11 & 3 & 3 & 28 & 5 \\
\hline $\mathrm{V} \quad 30-34 \mathrm{~m}$. & . - & 3 & 6 & 39 & 3 \\
\hline
\end{tabular}

This medusa was only taken in small numbers, but nevertheless there appears to be quite a marked assemblage at the surface at midnight; in all the other surface hauls it was absent save at 4 a.m., when one individual only was taken. 


\begin{tabular}{|c|c|c|c|c|c|}
\hline & 10 & PILA & For & ure 2). & \\
\hline & $\begin{array}{l}\text { 1st Series, } \\
3.25 \text { p.m. to } \\
4.45 \text { p.m. }\end{array}$ & $\begin{array}{l}\text { 2nd Series, } \\
7.55 \text { p.m. to } \\
9.17 \text { p.m. }\end{array}$ & $\begin{array}{l}\text { 3rd Series. } \\
10.50 \text { p.m. to } \\
12.20 \text { a.m. }\end{array}$ & $\begin{array}{l}\text { 4th Series, } \\
2.50 \text { a.m. to } \\
4.16 \text { a.m. }\end{array}$ & $\begin{array}{l}\text { 5th Series. } \\
8.45 \text { p.m. to } \\
10.11 \text { a.m. }\end{array}$ \\
\hline Surface & 7 & 217 & 700 & 517 & 5 \\
\hline & $1.2 \%$ & $44.5 \%$ & $71.3 \%$ & $31 \cdot 6 \%$ & $1.5 \%$ \\
\hline II & 36 & 103 & 46 & 484 & 44 \\
\hline $2-7 \mathrm{~m}$. & $5.9 \%$ & $22 \cdot 1 \%$ & $4.7 \%$ & $29 \cdot 6 \%$ & $13 \%$ \\
\hline III & 285 & 61 & 18 & 151 & 134 \\
\hline 9-15 m. & $46.9 \%$ & $12.5 \%$ & $1.8 \%$ & $9 \cdot 2 \%$ & $39.8 \%$ \\
\hline IV & 261 & 71 & 44 & 184 & 105 \\
\hline $6-20 \mathrm{~m}$. & $42.9 \%$ & $14.5 \%$ & $4.5 \%$ & $11 \cdot 2 \%$ & $31 \cdot 2 \%$ \\
\hline V & 19 & 31 & 174 & 301 & \\
\hline$-34 \mathrm{~m}$. & $3 \cdot 1 \%$ & $6 \cdot 4 \%$ & $17.7 \%$ & $18 \cdot 4 \%$ & $14.5 \%$ \\
\hline
\end{tabular}

[In this and all succeeding tables in which percentages occur, each catch is expressed as a percentage of the total number of individuals of that species caught at the five depths of the series in which it occurs.]

A definite migration to the surface at midnight was shown. In the daylight the region of greatest intensity was somewhere between 10 and 25 metres (Fig. 2).

By 9 p.m. the majority were caught above a depth of 10 metres, and at midnight they were taken in greatest numbers right at the surface. At dawn they were beginning to leave the surface, and at 10 the next morning their distribution was much as that of the previous afternoon.

There are no previous records of the vertical distribution of this species.

\section{LEPTOMEDUSA.}

\begin{tabular}{|c|c|c|c|c|c|}
\hline & \multicolumn{5}{|c|}{ OBELIA SP. } \\
\hline & $\begin{array}{l}\text { 1st Series. } \\
3.25 \text { p.m. to } \\
4.45 \text { p.m. }\end{array}$ & $\begin{array}{l}\text { 2nd Series. } \\
7.55 \text { p.m. to } \\
9.17 \text { p.m. }\end{array}$ & $\begin{array}{l}\text { 3rd Series. } \\
10.50 \text { p.m. to } \\
12.20 \text { a.m. }\end{array}$ & $\begin{array}{l}4 \text { th Series. } \\
2.50 \text { a.m. to } \\
4.16 \text { a.m. }\end{array}$ & $\begin{array}{l}5 \text { th Series. } \\
8.45 \text { a.m. to } \\
10.11 \text { a.m. }\end{array}$ \\
\hline Surface & - & 170 & 40 & 9 & - \\
\hline II $2-7 \mathrm{~m}$ & - & 50 & 10 & 1 & 50 \\
\hline III 9-15 m. & - & 270 & - & - & 2160 \\
\hline IV $16-20 \mathrm{~m}$ & ค. 540 & 1880 & 130 & - & 2690 \\
\hline V $30-34 \mathrm{~m}$ & ค. 30,600 & 18,670 & 14,852 & 830 & 6780 \\
\hline
\end{tabular}

At all hours Obelia had its maximum occurrence at 30-34 m., and probably deeper. In the first three series of hauls it was encountered in very dense swarms at this depth. It cannot be said that there was any marked movement towards the surface at night: there were certainly larger numbers present in the upper layers during the hours of darkness,

* The generic name Turris has been used here, although Mayer (12) remarks that the name is preoccupied and should be Clavula, as it will be more familiar to readers. 

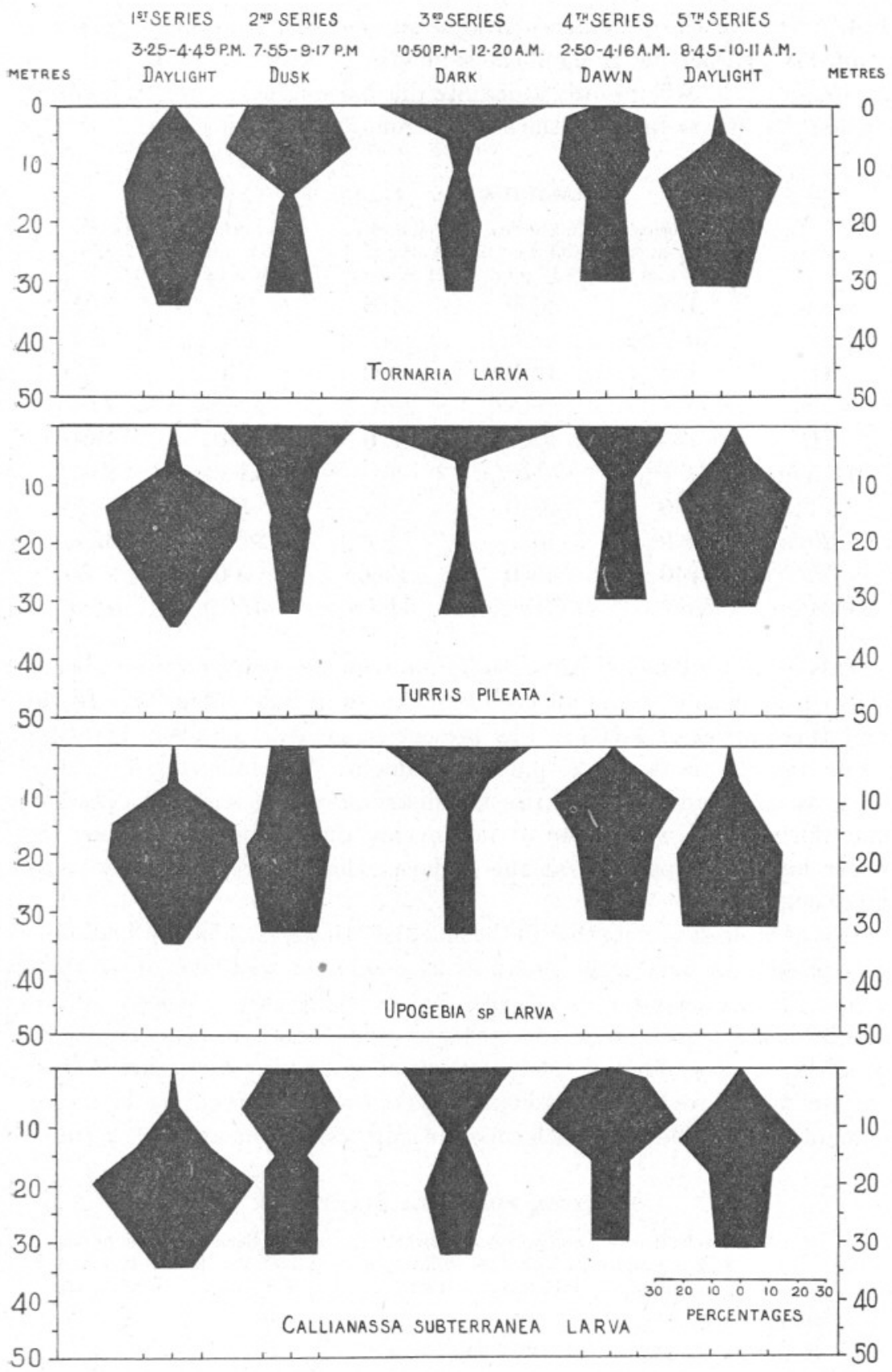

FIGURE 2. The vertical distribution of the above species between daylight, July 15th, and daylight, July 16th, 1924. The catch at each level has been expressed as a percentage of the total number caught in the five hauls of the series to which it belongs. These forms showed a definite migration to the surface in the dark hours. 
but in view of the very dense swarms present in the deeper layers it is doubtful whether much significance should be attached to it.

Gough (4, p. 345) records a definite diurnal migration in this medusa, noting that it was taken at the surface from 8 p.m. until 1 a.m.

\begin{tabular}{|c|c|c|c|c|c|}
\hline \multicolumn{6}{|c|}{ Phialidium sp. (Figure 4). } \\
\hline & $\begin{array}{l}\text { 1st Series. } \\
3.25 \text { p.m. to } \\
4.45 \text { p.m. }\end{array}$ & $\begin{array}{l}\text { 2nd Series. } \\
7.55 \text { p.m. to } \\
9.17 \text { p.m. }\end{array}$ & $\begin{array}{l}\text { 3rd Series. } \\
10.50 \text { p.m. to } \\
12.20 \text { a.m. }\end{array}$ & $\begin{array}{l}\text { 4th Series. } \\
2.50 \text { a.m. to } \\
4.16 \text { a.m. }\end{array}$ & $\begin{array}{l}\text { 5th Series. } \\
28.45 \text { a.m. to } \\
10.11 \text { a.m. }\end{array}$ \\
\hline Surface & 153 & 2330 & 460 & 4 & 720 \\
\hline & $10 \cdot 6 \%$ & $18 \cdot 3 \%$ & $16 \cdot 1 \%$ & $0.2 \%$ & $4 \cdot 1 \%$ \\
\hline II & & 7 & 290 & 240 & 3430 \\
\hline $2-7 \mathrm{~m}$. & $10 \cdot 6 \%$ & $15 \cdot 3 \%$ & $10 \cdot 2 \%$ & $12.7 \%$ & $19 \cdot 4 \%$ \\
\hline III & & & 170 & 640 & 49 \\
\hline $9-15 \mathrm{~m}$ & $11 \cdot 4 \%$ & $10 \cdot 9 \%$ & $6 \%$ & $33 \cdot 8 \%$ & $28.2 \%$ \\
\hline IV & & & 38 & 410 & 5660 \\
\hline $6-20 \mathrm{~m}$. & $9 \cdot 1 \%$ & $16 \%$ & $13 \cdot 3 \%$ & $21 \cdot 6 \%$ & $32 \%$ \\
\hline V & & & & 600 & 2890 \\
\hline $30-34 \mathrm{~m}$. & $58.3 \%$ & $39.5 \%$ & $54 \cdot 4 \%$ & $31 \cdot 7 \%$ & $16.3 \%$ \\
\hline
\end{tabular}

This form, probably chiefly Phialidium hemisphericum, on this occasion showed no signs of being affected by changes in light intensity. In the first three series of hauls it was present in greatest numbers at about 30 metres, that is from 3.25 p.m. to midnight. The following day, however, at dawn and after sunrise the distribution is somewhat different, and the medusæ were more or less evenly distributed throughout the water layers except right at the surface, where there were only small numbers (Fig. 4).

It is of interest to note that in the 2 nd and 5th series of hauls Phialidium was present in very large numbers as compared with the other three series. It is reasonable to suppose that on these two occasions the net was fishing in a dense area, and seeing that the large numbers are present in all layers some idea of the size of these areas may be gathered from the fact that it took about $1 \frac{1}{2}$ hours to take the full series of hauls in each case during the whole of which time the ship was towing at about 2 knots.

\section{Cosmetira pilosella Hartlaub.}

\begin{tabular}{|c|c|c|c|c|c|}
\hline & $\begin{array}{l}\text { 1st Series. } \\
3.25 \text { p.m. to } \\
4.45 \text { p.m. }\end{array}$ & $\begin{array}{l}\text { 2nd Series. } \\
7.55 \text { p.m. to } \\
9.17 \text { p.m. }\end{array}$ & $\begin{array}{l}\text { 3rd Series. } \\
10.50 \text { p.m. to } \\
12.20 \text { a.m. }\end{array}$ & $\begin{array}{l}\text { 4th Series. } \\
2.50 \text { p.m. to } \\
4.16 \mathrm{a} . \mathrm{m} \text {. }\end{array}$ & $\begin{array}{l}5 \text { th Series. } \\
8.45 \text { a.m. to } \\
10.11 \text { a.m. }\end{array}$ \\
\hline Surface & - & 19 & 24 & - & - \\
\hline II $2-7 \mathrm{~m}$. & - & 26 & 1 & 一 & 1 \\
\hline III 9-15 m. & - & 22 & - & 13 & 59 \\
\hline IV $16-20 \mathrm{~m}$. & 1 & 45 & 1 & 11 & 13 \\
\hline $\mathrm{V} \quad 30-34 \mathrm{~m}$. & 3 & 25 & 6 & 28 & 9 \\
\hline
\end{tabular}



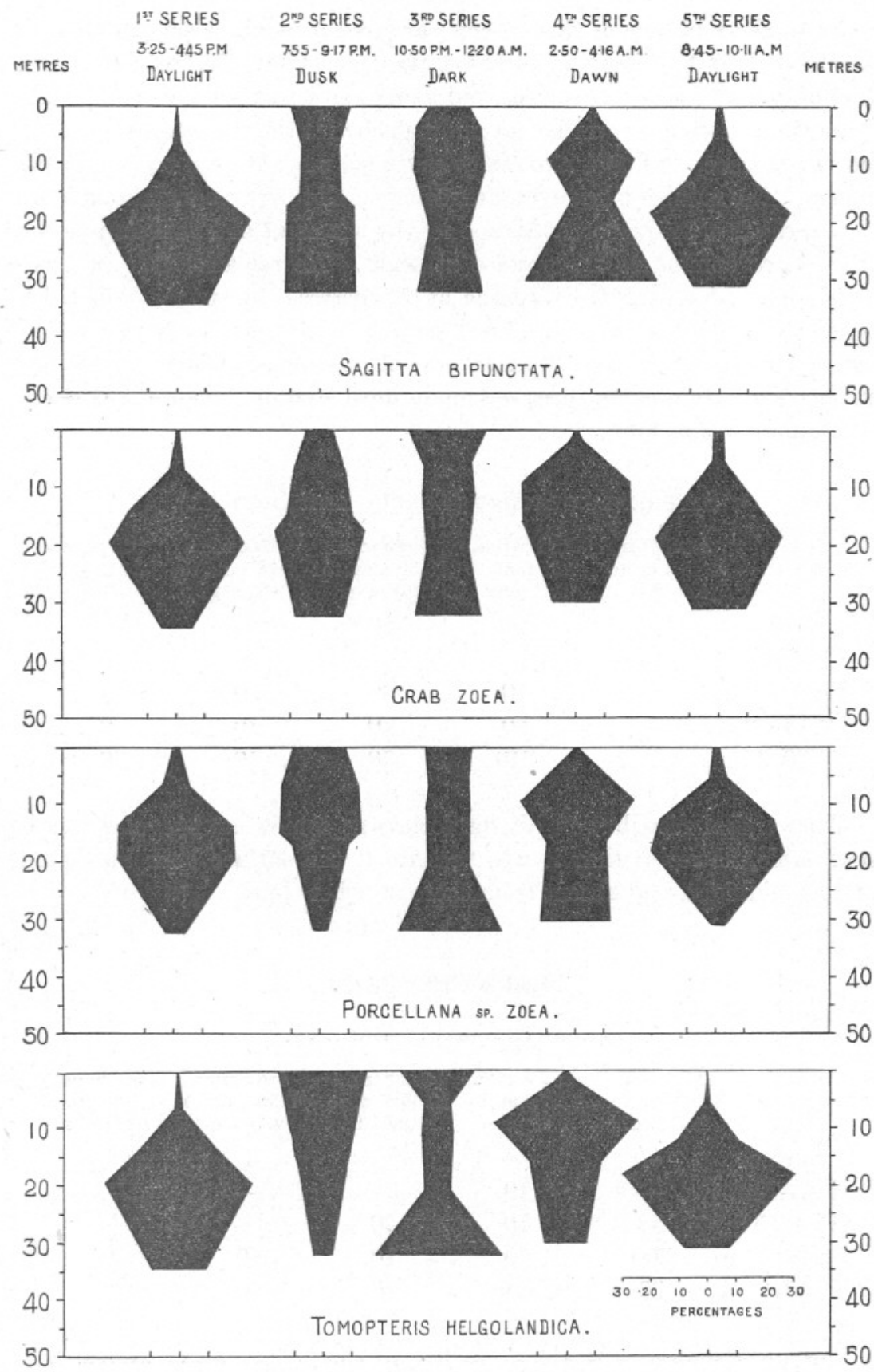

Figure 3. The vertical distribution of the above species between daylight, July 15th, and daylight, July 16th, 1924. The catch at each level has been expressed as a percentage of the total number caught in the five hauls of the series to which it belongs. The three upper forms showed an expansion of their day distribution into the surface layers, 
From the numbers of this species captured it would seem that here is shown a definite migration to the surface at night. In the daytime it was only taken below 12 metres, but at 9 p.m. it was present in all layers from the surface downwards : at midnight by far the majority were taken on the surface, and at 4 a.m. they had once more retired to the deeper layers. The numbers, however, are rather small to draw conclusions from.

Gough $(4$, p. 345$)$ records this species (by the name of Euchilota pilosella Forbes) as coming to the surface at night. He remarks that it "was only observed during the daytime at 30 metres; at sunset it had disappeared from the 30 -metre level, and had not yet appeared at the 10- or 1-metre level. By 10 p.m. it was at the surface, where it remained until 1 a.m. It was not observed again until 10 a.m., when it was taken at 30 metres once more."

\begin{tabular}{|c|c|c|c|c|c|}
\hline & SAPPHENIA & GRACILIS & FORBES AND & GoodsIR). & \\
\hline & $\begin{array}{l}\text { 1st Series. } \\
3.25 \text { p.m. to } \\
4.45 \text { p.m. }\end{array}$ & $\begin{array}{l}\text { 2nd Series. } \\
7.55 \text { p.m. to } \\
9.17 \text { p.m. }\end{array}$ & $\begin{array}{l}\text { 3rd Series. } \\
10.50 \text { p.m. to } \\
12.20 \text { a.m. }\end{array}$ & $\begin{array}{l}\text { 4th Series. } \\
2.50 \text { a.m. to } \\
4.16 \text { a.m. }\end{array}$ & $\begin{array}{l}\text { 5th Series. } \\
8.45 \text { a.m. to } \\
10.11 \text { a.m. }\end{array}$ \\
\hline Surface & - & 26 & 20 & - & - \\
\hline II $2-7 \mathrm{~m}$. & - & 一 & 一 & 2 & - \\
\hline III 9-15 m. & - & 50 & 30 & 20 & - \\
\hline IV $16-20 \mathrm{~m}$ & - & 90 & 10 & 10 & 30 \\
\hline V $30-34 \mathrm{~m}$ & - & 210 & 50 & 10 & 70 \\
\hline
\end{tabular}

The vertical distribution of this form was somewhat irregular; it is noticeable, however, that it was present at the surface both at 9 p.m. and at midnight, and absent from there at other times.

\section{TRACHYMIEDUSAE.}

\section{Aglantha rosea Browne.}

\begin{tabular}{|c|c|c|c|c|c|}
\hline & $\begin{array}{l}\text { Ist Series. } \\
.25 \text { p.m. to } \\
4.45 \text { p.m. }\end{array}$ & $\begin{array}{l}\text { 2nd Series. } \\
7.55 \text { p.m. to } \\
9.17 \text { p.m. }\end{array}$ & $\begin{array}{l}\text { 3rd Series. } \\
10.50 \mathrm{a} . \mathrm{m} \text {. to } \\
12.20 \mathrm{a} . \mathrm{m} .\end{array}$ & $\begin{array}{l}\text { 4th Series. } \\
2.50 \mathrm{a} . \mathrm{m} . \text { to } \\
4.16 \mathrm{a} . \mathrm{m} .\end{array}$ & $\begin{array}{l}\text { 5th Series. } \\
8.45 \text { a.m. to } \\
10.11 \text { a.m. }\end{array}$ \\
\hline Surface & - & - & - & 1 & - \\
\hline II $2-7 \mathrm{~m}$. & - & 10 & - & - & - \\
\hline III $9-15 \mathrm{~m}$. & 58 & 10 & 20 & - & - \\
\hline IV $16-20 \mathrm{~m}$. & 200 & 50 & 10 & 40 & 10 \\
\hline V $30-34 \mathrm{~m}$. & 30 & 110 & 30 & 20 & 10 \\
\hline
\end{tabular}

This form showed a tendency to live in the deeper water layers, and from the numbers captured it would appear that there was little vertical movement at night. 
VERTICAL DISTRIBUTION OF MACROPLANKTON.
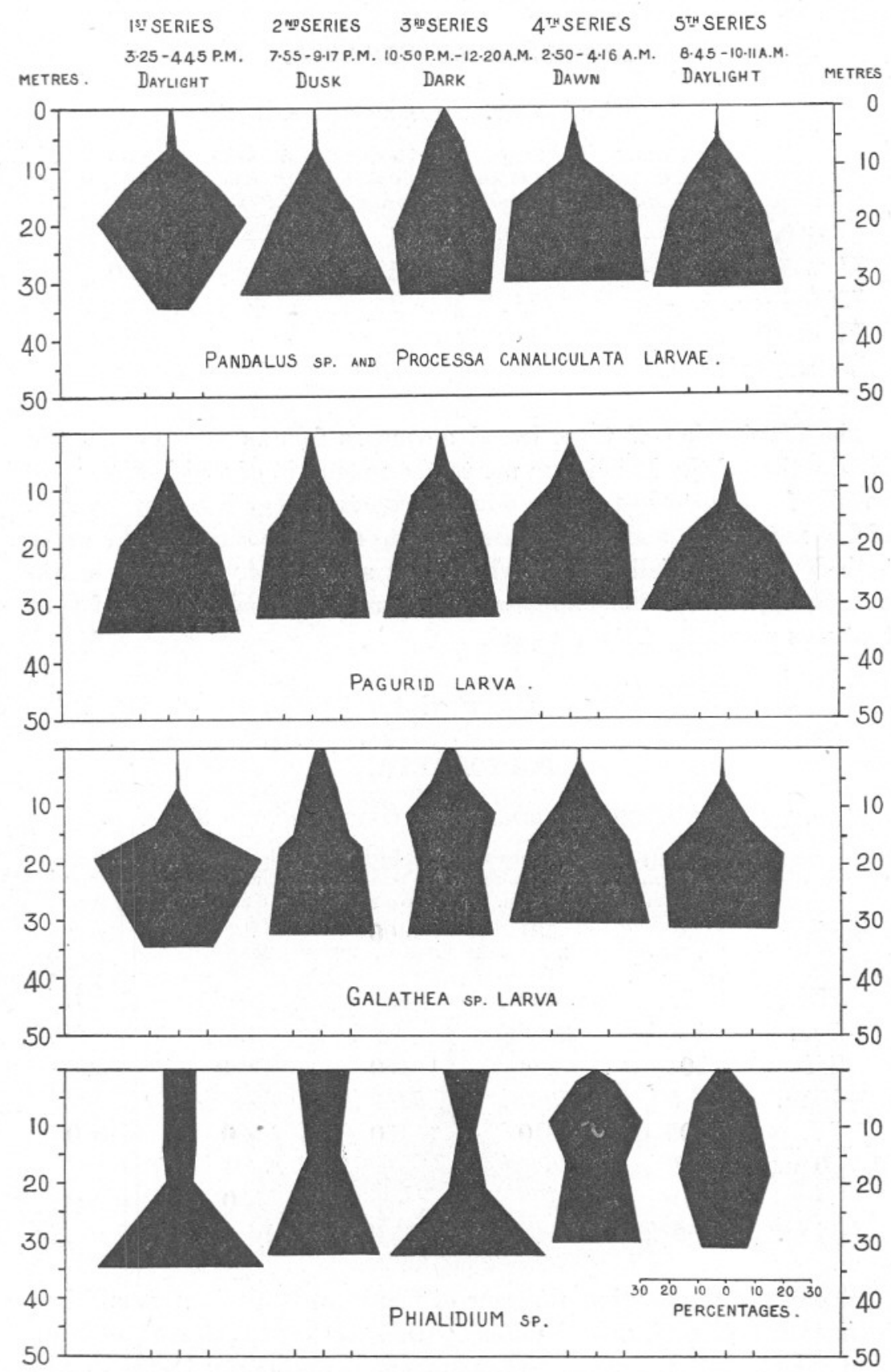

FIGURE 4. The vertical distribution of the above species between daylight, July 15th, and daylight, July 16 th, 1924 . The catch at each level has been expressed as a percentage of the total number caught in the five hauls of the series NEW SERIES. - VOL. XIII. No. 4. OCTOBER, 1925.

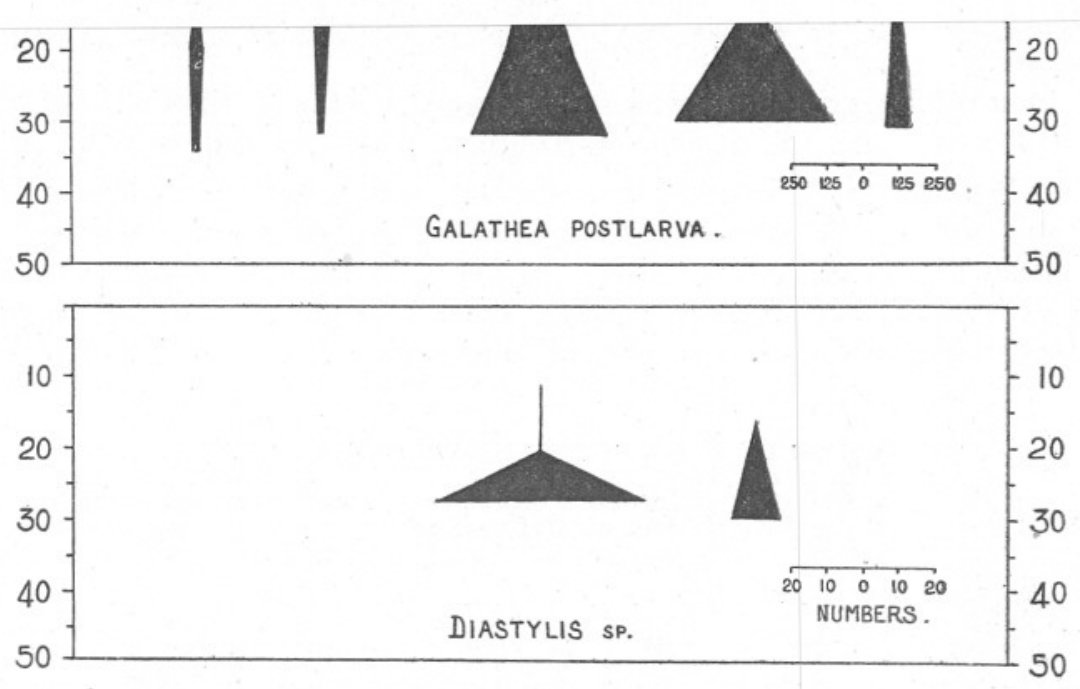

FIGURe 5. The vertical distribution of the above species between daylight, July 15th, and daylight, July 16th, 1924, showing actual numbers caught at each depth. These are bottom living forms, or deep living by day, which moved upwards at night, 


\section{ANTHOZOA-ZOANTHARIA.}

Peachia sp. Young Stages.

\begin{tabular}{|c|c|c|c|c|c|}
\hline & $\begin{array}{l}\text { lst Series. } \\
3.25 \text { p.m. to } \\
4.45 \text { p.m. }\end{array}$ & $\begin{array}{l}\text { 2nd Series. } \\
7.55 \text { p.m. to } \\
9.17 \text { p.m. }\end{array}$ & $\begin{array}{l}\text { 3rd Series. } \\
10.50 \text { p.m. to } \\
12.20 \mathrm{a} . \mathrm{m} .\end{array}$ & $\begin{array}{l}\text { 4th Series. } \\
2.50 \text { a.m. to } \\
4.16 \text { a.m. }\end{array}$ & $\begin{array}{l}\text { 5th Series. } \\
8.45 \text { a.m. to } \\
10.11 \text { a.m. }\end{array}$ \\
\hline Surface & - & 11 & 1 & - & 1 \\
\hline II $2-7 \mathrm{~m}$. & 一 & 7 & 1 & 一 & 20 \\
\hline III 9-15 m. & 一 & 14 & 1 & 4 & 23 \\
\hline IV $16-20 \mathrm{~m}$. & 5 & 14 & 4 & 3 & 24 \\
\hline $\mathrm{V} \quad 30-34 \mathrm{~m}$ & 2 & 21 & 14 & 1 & 19 \\
\hline
\end{tabular}

The distribution of these larval anemones follows very closely the distribution of the Phialidium sp. to the manubria of which they were usually found attached. It is doubtful whether they have any powers of free movement, and they are dependent on their position in the water entirely on the Phialidium by which they are carried, and must consequently display the same apparent disregard to diurnal changes of light that was shown by these medusæ.

\section{ANNELIDA.}

\section{POLYCHAETA.}

Tomopteris helgolandica Greef (Figure 3).

$\begin{array}{ccccc}\text { 1st Series. } & \text { 2nd Series. } & \text { 3rd Series. } & \text { 4th Series. } & \text { 5th Series. } \\ 3.25 \text { p.m. } & 7.55 \text { p.m. to } & 10.50 \text { p.m. to } & 2.50 \text { a.m. to } & 8.45 \text { a.m. to } \\ 4.45 \text { p.m. } & 9.17 \text { p.m. } & 12.20 \text { a.m. } & 4.16 \text { a.m. } & 10.11 \text { a.m. } \\ 3 & 581 & 400 & 46 & 2 . \\ 0.7 \% & 31 \cdot 7 \% & 25 \cdot 4 \% & 1 \cdot 3 \% & 0 \cdot 1 \% \\ 13 & 460 & 150 & 312 & 20 \\ 3 \cdot 2 \% & 25 \cdot 1 \% & 9 \cdot 5 \% & 8 \cdot 5 \% & 1 \cdot 4 \% \\ 108 & 360 & 180 & 1880 & 300 \\ 26 \cdot 4 \% & 19 \cdot 7 \% & 11 \cdot 4 \% & 50 \cdot 9 \% & 21 \cdot 6 \% \\ 205 & 310 & 150 & 920 & 840 \\ 50 \cdot 1 \% & 16 \cdot 9 \% & 9 \cdot 5 \% & 24 \cdot 9 \% & 60 \cdot 4 \% \\ 80 & 120 & 695 & 530 & 230 \\ 19 \cdot 6 \% & 6 \cdot 6 \% & 44 \cdot 1 \% & 14 \cdot 4 \% & 16 \cdot 5 \%\end{array}$

Whereas in the daytime the zone of maximum abundance was below 10 metres, at 9 p.m. and at midnight this species was present in large numbers right on the surface, the numbers diminishing with the depth. At midnight there were still large numbers on the surface and fewer deeper down; in the bottom haul, however, a large catch of 695 was 


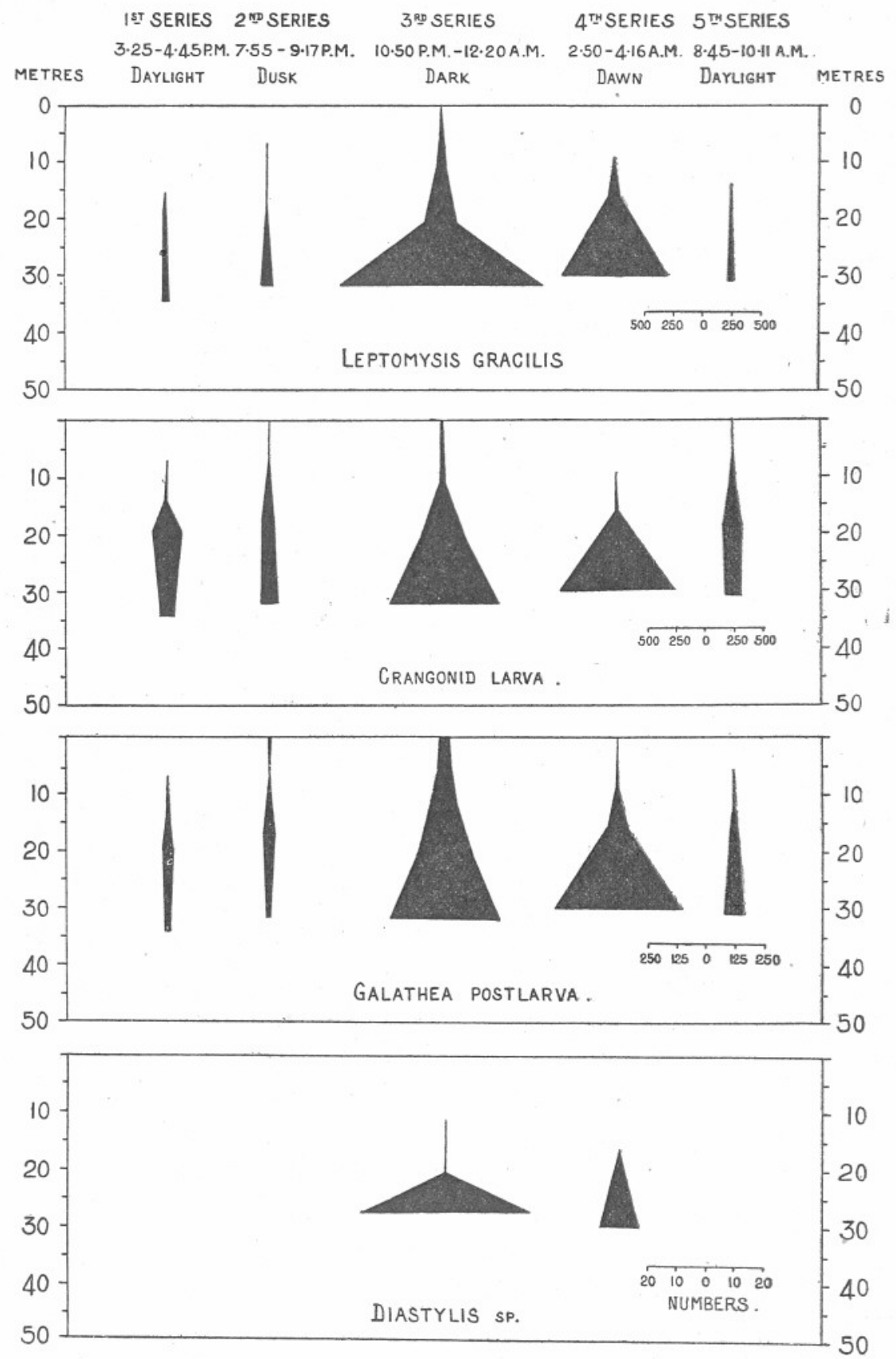

FIgURE 5. The vertical distribution of the above species between daylight, July 15th, and daylight, July 16th, 1924, showing actual numbers caught at each depth. These are bottom living forms, or deep living by day, which moved upwards at night, 
taken; but it is noteworthy that these were nearly all very small individuals, and there were few of the large adults which were so marked a feature of the upper layers.

It is probable that there is exhibited here a definite migration to the surface layers ; the diagram (Fig. 3), however, does not show the typical migration figure on account of the large number of small individuals encountered in the bottom haul. There is a possibility that the behaviour of the smaller forms differs somewhat from that of the full-grown adults : their swimming powers would not be so great, and in the upward migration they would tend to be left behind: this appears also in Series IV and $\mathrm{V}$ at dawn and daylight in which at $4 \mathrm{a} . \mathrm{m}$. the catches of 46 at the surface and 312 at 2 metres both consisted chiefly of small worms, as did that of 300 individuals at 12.5 metres at 9.30 a.m., showing again that the large forms were able to return quicker to the deep water.

Gough (4), on July 1st to 2nd, 1903, observed the vertical movements of Tomopteris, using the Garstang closing net at four depths: $1 \mathrm{~m}$., $10 \mathrm{~m}$., $30 \mathrm{~m}$., and $70 \mathrm{~m}$. He says : "During the hottest part of the day the bulk of the Tomopteris was found near the bottom at 70 metres, only very few being at 30 metres. Shortly before sunset single specimens were found at 10 metres and 35 metres, the majority being still at the bottom. At 10 p.m. they had reached the surface, being in all layers from the bottom upwards. They remained at the surface till $12.55 \mathrm{a} . \mathrm{m}$. At 3.50 a.m. they had left the top layers and retired to 10 metres and lower; by 7 a.m. they had sunk still deeper, not being found above 30 metres. By midday on July 2 nd, most of them were again at 70 metres."

These results agree closely with mine, especially in the distributions from 9 p.m. to 4 a.m. : the daylight distributions, however, differ somewhat but Gough's observations were made in much deeper and probably clearer water. My daytime catches showed a maximum abundance between 15 and 30 metres : at 9 p.m. and midnight they were present in all layers from surface to bottom, and at $4 \mathrm{a.m}$. the majority had retired from the surface to a depth of 10 metres.

Larve of Pecilochetus serpens Allen.

\begin{tabular}{|c|c|c|c|c|c|}
\hline & $\begin{array}{l}\text { 1st Series. } \\
3.25 \text { p.m. to } \\
4.45 \text { p.m. }\end{array}$ & $\begin{array}{l}\text { 2nd Series. } \\
7.55 \text { p.m. to } \\
9.17 \text { p.m. }\end{array}$ & $\begin{array}{l}\text { 3rd Series. } \\
10.50 \text { p.m. to } \\
12.20 \text { a.m. }\end{array}$ & $\begin{array}{l}\text { 4th Series. } \\
2.50 \text { a.m. to } \\
4.16 \text { a.m. }\end{array}$ & $\begin{array}{l}5 \text { th Series. } \\
8.45 \text { a.m. to } \\
10.11 \text { a.m. }\end{array}$ \\
\hline Surface & - & - & - & - & 一 \\
\hline II $2-7 \mathrm{~m}$. & 1 & 10 & 一 & 1 & 一 \\
\hline II $9-15 \mathrm{~m}$. & 8 & - & 一 & 一 & 80 \\
\hline IV $16-20 \mathrm{~m}$. & 50 & 110 & 一 & 10 & 100 \\
\hline V $\quad 30-34 \mathrm{~m}$. & 90 & 300 & 40 & 20 & 50 \\
\hline
\end{tabular}



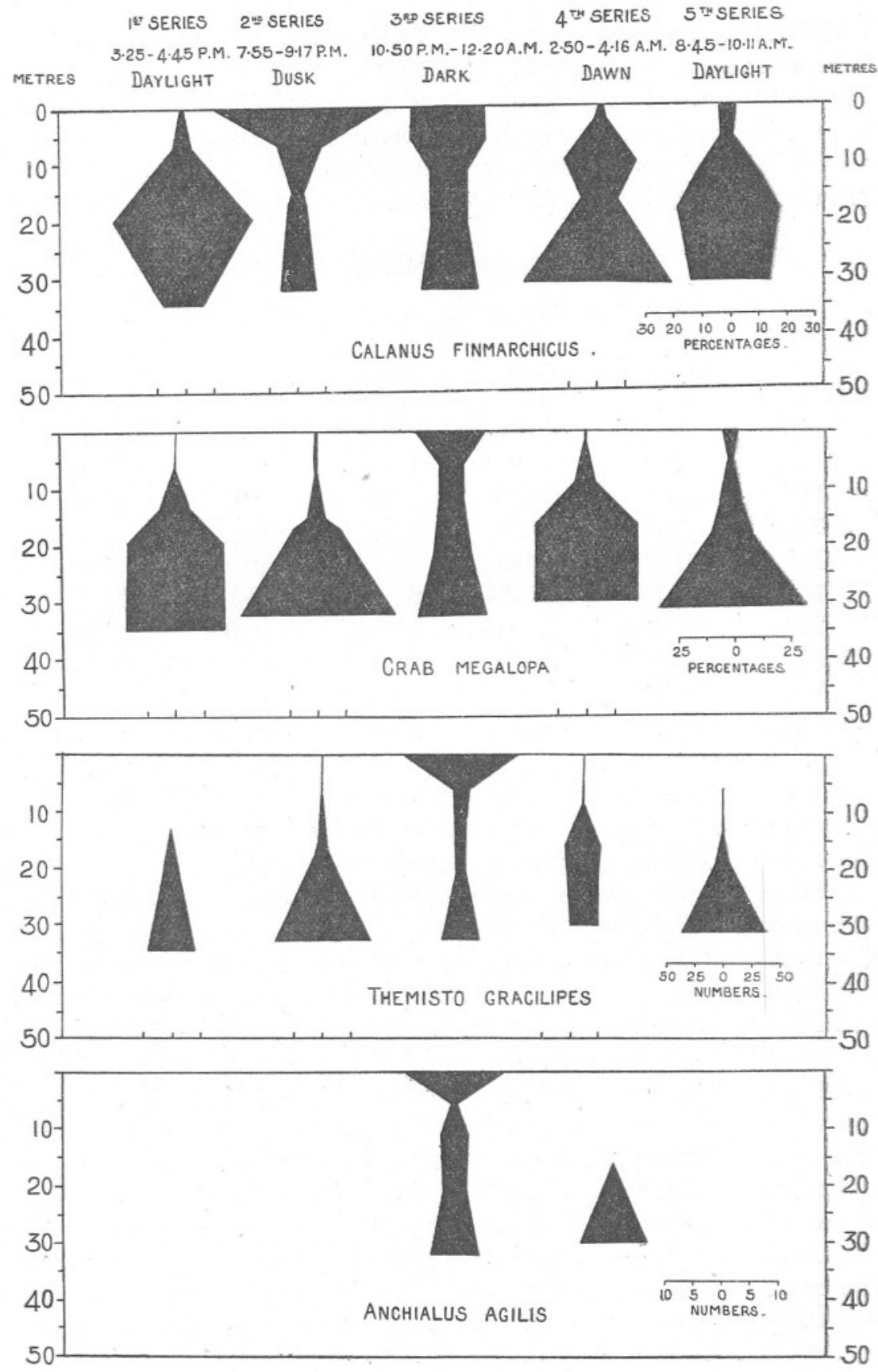

Figure 6. The vertical distribution of the above species between daylight, July 15th, and daylight, July 16th, 1924. Calanus, Themisto and Anchialus shows definite migrations to the surface. 
The very characteristic larva of this seldom seen polychaete was taken in greatest abundance only in the deeper layers by night as well as by day, and there was no marked movement unless the large number taken at 30 metres at 8 p.m. has any significance. If this was so we would gather that at other times the larva was most abundant in the layers below 30 metres, and that at dusk it had risen slightly higher in the water.

\section{CHETOGNATHA.}

\section{Sagitta bipunctata Quoy and Gaimard (Figure 3).}

\begin{tabular}{|c|c|c|c|c|c|}
\hline & $\begin{array}{l}\text { 1st Series. } \\
3.25 \text { p.m. to } \\
4.45 \text { p.m. }\end{array}$ & $\begin{array}{l}\text { 2nd Series. } \\
7.55 \text { p.m. to } \\
9.17 \text { p.m. }\end{array}$ & $\begin{array}{l}\text { 3rd Series. } \\
10.50 \text { p.m. to } \\
12.20 \text { a.m. }\end{array}$ & $\begin{array}{l}\text { 4th Series. } \\
2.50 \mathrm{a} . \mathrm{m} \text {. to } \\
4.16 \mathrm{a} . \mathrm{m} \text {. }\end{array}$ & $\begin{array}{l}5 \text { th Series. } \\
8.45 \text { a.m. to } \\
10.11 \text { a.m. }\end{array}$ \\
\hline Surface & 98 & 2060 & 1040 & 66 & 355 \\
\hline & $1 \cdot 8 \%$ & $21 \cdot 8 \%$ & $14.9 \%$ & $2 \cdot 1 \%$ & $2.5 \%$ \\
\hline II & 196 & 1230 & 1600 & 203 & 760 \\
\hline $2-7 \mathrm{~m}$. & $3.5 \%$ & $13 \%$ & $23 \%$ & $6 \cdot 2 \%$ & $5 \cdot 3 \%$ \\
\hline III & 1195 & 1460 & 1760 & 1010 & 3400 \\
\hline $9-15 \mathrm{~m}$. & $21 \cdot 3 \%$ & $15 \cdot 5 \%$ & $25 \cdot 3 \%$ & $30 \cdot 8 \%$ & $23.7 \%$ \\
\hline IV & 2925 & 2290 & 990 & 490 & 7130 \\
\hline $6-20 \mathrm{~m}$. & $52 \cdot 2 \%$ & $24 \cdot 3 \%$ & $14 \cdot 2 \%$ & $14.9 \%$ & $49.7 \%$ \\
\hline $\mathrm{V}$ & 1190 & 2400 & 1573 & 1510 & 2710 \\
\hline $30-34 \mathrm{~m}$. & $21 \cdot 2 \%$ & $25 \cdot 4 \%$ & $22.6 \%$ & $46 \%$ & $18.8 \%$ \\
\hline
\end{tabular}

In the daylight Sagitta bipunctata occurred in greatest abundance below a depth of 6 metres. By 9 p.m. it was taken in more or less equal numbers from the surface down to 31 metres; a similar distribution was maintained at midnight. At dawn the following day the upper 10 metres were again comparatively empty (Fig. 3).

The vertical distribution of this species has been worked up at length by Michael in the San Diego region (13). He concludes that between 6 a.m. and 6 p.m. the species is most abundant between 15 and 20 fathoms (ca. 27-36 m.), and between 6 p.m. and 6 a.m. it is most abundant above 15 fathoms. Further, that it has a maximum abundance at the surface within an hour after sunset, and then deserts the surface returning to cause a second maximum within an hour after sunrise.

Herdman, Scott (9) say: "A haul of the shear-net five miles off land at about 10 fathoms, on April 14th, gave 301 large specimens of Sagitta, although the surface nets worked at the same time caught none. . . This result suggests that at that time, although not present at the surface, Sagitta was abundant a few fathoms below." And in later papers similar remarks on the distribution in the daytime point to the most populous zone being a few fathoms below the surface. 


\section{CRUSTACEA.}

\section{COPEPODA.}

Calanus finmarchicus (Gunner) (Figure 6).

\begin{tabular}{|c|c|c|c|c|c|}
\hline & $\begin{array}{l}\text { 1st Series. } \\
3.25 \text { p.m. to } \\
4.45 \text { p.m. }\end{array}$ & $\begin{array}{l}\text { 2nd Series. } \\
7.55 \text { p.m. to } \\
9.17 \text { p.m. }\end{array}$ & $\begin{array}{l}\text { 3rd Series. } \\
10.50 \text { p.m. to } \\
12.20 \text { a.m. }\end{array}$ & $\begin{array}{l}\text { 4th Series. } \\
2.50 \text { a.m. to } \\
4.16 \text { a.m. }\end{array}$ & $\begin{array}{l}5 \text { th Series. } \\
8.45 \text { a.m. to } \\
10.11 \text { a.m. }\end{array}$ \\
\hline Surface & $\begin{array}{l}27 \\
1 \cdot 1 \%\end{array}$ & $\begin{array}{l}4814 \\
60 \cdot 1 \%\end{array}$ & & $\begin{array}{l}63 \\
2 \cdot 4 \%\end{array}$ & $\begin{array}{l}150 \\
6 \cdot 4 \%\end{array}$ \\
\hline II & 171 & 1200 & 2450 & 168 & $110^{\prime}$ \\
\hline $2-7 \mathrm{~m}$. & $6 \cdot 6 \%$ & $15 \%$ & $26 \cdot 7 \%$ & $6 \cdot 4 \%$ & $4.7 \%$ \\
\hline III & 747 & 420 & 1190 & 700 & 560 \\
\hline $\begin{array}{c}9-15 \mathrm{~m} . \\
\text { IV }\end{array}$ & $\begin{array}{c}28.9 \% \\
1265\end{array}$ & $\begin{array}{l}5 \cdot 1 \% \\
590\end{array}$ & $\begin{array}{l}13 \cdot 1 \% \\
1280\end{array}$ & $\begin{array}{c}26 \cdot 5 \% \\
320\end{array}$ & $\begin{array}{l}24 \cdot 1 \% \\
840\end{array}$ \\
\hline $16-20 \mathrm{~m}$. & $49 \%$ & $7 \cdot 4 \%$ & $13.9 \%$ & $12 \cdot 1 \%$ & $36 \%$ \\
\hline $\mathrm{V}$ & 370 & 990 & 1826 & 1390 & 670 \\
\hline $30-34 \mathrm{~m}$. & $14 \cdot 4 \%$ & $12 \cdot 4 \%$ & $20 \cdot 0 \%$ & $52.6 \%$ & $28.8 \%$ \\
\hline
\end{tabular}

This species was taken in the greatest numbers in the daytime at a depth of about 20 metres. It was present in small numbers above 6 metres, but below this at 12 metres there was a sudden large increase in abundance. By 9 p.m. large numbers had collected between 0 and 7 metres, and by far the majority were captured in the surface haul. At midnight the distribution was more or less even from surface to 30 metres with a tendency to larger numbers in the upper layers. By 4 a.m. Calanus was again seeking the deeper layers (Fig. 6). Whether there is any significance in the fact that at this time (4th series) the greatest number were caught in the deepest haul at 30 metres it is impossible to say from a single record, but it is curious that this dawn distribution is exactly similar to that shown by Sagitta bipunctata (Fig. 3).

Esterley has shown a similar diurnal migration of Calanus in the San Diego region, California (2). He found the region of maximum abundance in the daytime to be at 200 fathoms, in the evening at 100 fathoms, and at midnight at 5 to 10 fathoms, while from 4 to 6 a.m, it is at 100 fathoms.

He says: "The animals appear to leave the surface before the light increases at all in intensity. This suggests that decreasing light is not the cause of the downward movement" (p. 337).

I have no observation between 12.20 and 4 a.m. at the surface, but at any rate the 12.20 haul in the 3 rd series indicates that they had already started to leave the surface.

Although naturally my depths of the various maxima do not agree with Esterley's results on account of the shallowness of the water and the 
greater turbidity of coastal waters and probably the lesser strength of the light due to the differences in latitude, the general type of movement shown is in very close agreement.

Farran (3) says : ". . . while eggs and larvæ are to be found chiefly at the surface the main body of adult spawners occurs deeper, as Damas shows for the larger northern forms . . . adults occurring at 20-100 m."

\section{Candacia armata Boeck.}

$\begin{array}{cccccc} & \text { 1st Series. } & \text { 2nd Series. } & \text { 3rd Series. } & \text { 4th Series. } & \text { 5th Series. } \\ & 3.25 \text { p.m. to } & 7.55 \text { p.m.t } & 10.50 \text { p.m. to } & 2.50 \text { a.m. to } & 8.45 \text { a.m. to } \\ & 4.45 \text { p.m. } & 9.17 \text { p.m. } & 12.20 \text { a.m. } & 4.16 \text { a.m. } & 10.11 \text { a.m. } \\ \text { Surface } & 1 & 572 & 220 & 2 & - \\ & 0 \cdot 2 \% & 30 \cdot 9 \% & 24 \cdot 5 \% & 0 \cdot 5 \% & 0 \cdot 0 \% \\ \text { II } & 11 & 160 & 180 & 20 & 30 \\ \text { 2-7 m. } & 2 \cdot 4 \% & 8 \cdot 7 \% & 20 \% & 5 \% & 5 \cdot 2 \% \\ \text { III } & 83 & 270 & 150 & 130 & 20 \\ \text { 9-15 m. } & 17 \cdot 6 \% & 14 \cdot 6 \% & 16 \cdot \% \% & 31 \cdot 5 \% & 3 \cdot 5 \% \\ \text { IV } & 235 & 330 & 90 & 130 & 90 \\ \text { 16-20 m. } & 50 \% & 17 \cdot 7 \% & 10 \% & 31 \cdot 5 \% & 15 \cdot 5 \% \\ \text { V } & 140 & 520 & 300 & 130 & 440 \\ 30-34 \mathrm{~m} . & 29 \cdot 8 \% & 28 \cdot 1 \% & 28 \cdot 8 \% & 31 \cdot 5 \% & 75 \cdot 8 \%\end{array}$

In daylight this copepod was present in greatest numbers below $13 \mathrm{~m}$. : by 9 p.m. it was taken in the surface hauls in large numbers, and was still present there at midnight. By 4 a.m. it had again left the surface layers. This behaviour would appear to have been very similar to that of Calanus finmarchicus, except that at 8 p.m. it was taken in large numbers at a depth of $30 \mathrm{~m}$. as well as at the surface.

Scott remarks (16) : "Though it may not be described as a deep-water species, it is frequently obtained at moderate depths. Its vertical range, however, does not appear to greatly exceed $200 \mathrm{~m}$."

Gough (4, p. 336) says that it "occurs in all depths in the Channel from 150 metres to the surface, and is usually commoner in the lower layers."

\section{Anomalocera Patersoni Templeton.}

\begin{tabular}{|c|c|c|c|c|c|}
\hline & $\begin{array}{l}\text { eries. } \\
\text { p.m. to } \\
\text { p.m. }\end{array}$ & $\begin{array}{l}\text { 2nd Series. } \\
7.55 \text { p.m. to } \\
9.17 \text { p.m. }\end{array}$ & $\begin{array}{l}\text { 3rd Series. } \\
10.50 \text { p.m. to } \\
12.20 \text { a.m. }\end{array}$ & $\begin{array}{l}\text { 4th Series. } \\
2.50 \text { a.m. to } \\
4.16 \text { a.m. }\end{array}$ & $\begin{array}{l}5 \text { th Series. } \\
8.45 \text { a.m. to } \\
10.11 \text { a.m. }\end{array}$ \\
\hline Surface & 27 & 25 & 204 & 7 & 26 \\
\hline II $2-7 \mathrm{~m}$. & 16 & 16 & 16 & 5 & 13 \\
\hline III 9-15 m. & 6 & 5 & 20 & 171 & 23 \\
\hline IV $16-20 \mathrm{~m}$. & 8 & 9 & 29 & 172 & 50 \\
\hline $\mathrm{V} \quad 30-34 \mathrm{~m}$. & 2 & 11 & 36 & 30 & 26 \\
\hline
\end{tabular}


This copepod would appear to be undisturbed by changes in light. On this occasion it was taken in greatest numbers on the surface at 4.30 p.m., at 9 p.m., and at midnight; but at dawn the next day it appeared in much larger quantities at 9 and $16 \mathrm{~m}$. than elsewhere, and by daylight it was present in all layers from the surface to $30 \mathrm{~m}$.

Scott (16, p. 142) says: "Its usual habit is to swim at or near the surface. . . . Although its vertical range is said to extend from the surface to about $700 \mathrm{~m}$. it appears to be rarely met with in such deep water."

Gough (4, p. 336) says: " A. Patersoni is usually found at the surface, very rarely descending to 10 metres. In August, however, a few specimens . . . were found in a sample from 110 metres."

Seeing that this form is evidently capable of enduring the strongest light often living at the surface in the daytime it seems unlikely that it would show diurnal rhythm due to changes in light. It is possible, though, that on account of its carnivorous and predatory habits, as shown by Lebour (11), it might exhibit feeding migrations and that its presence in deeper layers at dawn, on this occasion, could be accounted for by its having followed its food down from the surface where it was abundant at night.

\section{CAligus SP.}

\begin{tabular}{|c|c|c|c|c|c|}
\hline & $\begin{array}{l}\text { Ist Series. } \\
.25 \text { p.m. to } \\
4.45 \text { p.m. }\end{array}$ & $\begin{array}{l}\text { 2nd Series. } \\
7.55 \text { p.m. to } \\
9.17 \text { p.m. }\end{array}$ & $\begin{array}{l}\text { 3rd Series. } \\
10.50 \text { p.m. to } \\
12.20 \text { a.m. }\end{array}$ & $\begin{array}{l}\text { 4th Series. } \\
2.50 \text { a.m. to } \\
4.16 \text { a.m. }\end{array}$ & $\begin{array}{l}\text { 5th Series. } \\
8.45 \text { a.m. to } \\
10.11 \text { a.m. }\end{array}$ \\
\hline Surface & - & 1 & - & - & 1 \\
\hline Il $2-7 \mathrm{~m}$. & 1 & 3 & 3 & 2 & 一 \\
\hline III $9-15 \mathrm{~m}$. & 2 & 3 & 2 & 2 & 6 \\
\hline IV $16-20 \mathrm{~m}$ & 5 & 1 & 2 & 4 & 4 \\
\hline $\mathrm{V} \quad 30-34 \mathrm{~m}$. & 1 & 2 & 2 & 2 & 4 \\
\hline
\end{tabular}

Free-swimming forms were not abundant, and the numbers taken were insufficient to show vertical distribution; but they show the possibility that this form is evenly distributed through all layers by night, tending to be more abundant below 6 metres in the daytime.

\section{MYSIDACEA.}

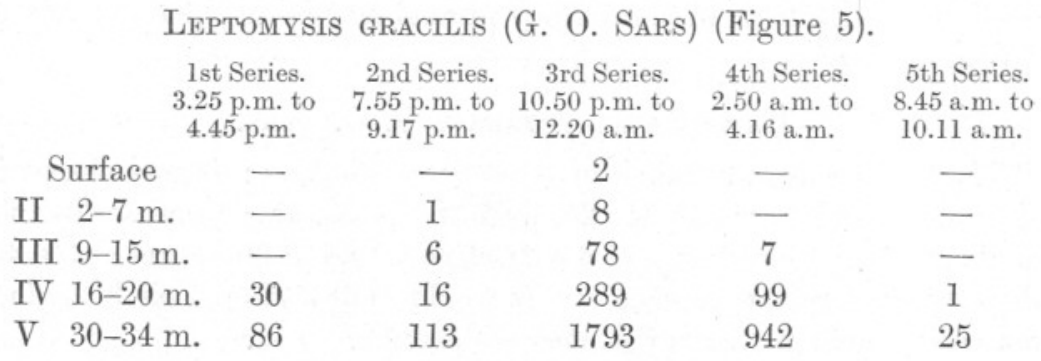


In the daytime this Mysid was taken in small numbers at 20 and 30 metres only; at dusk the number in the lower layers had increased slightly, and one individual was taken at a depth of 7 metres. At midnight the number taken at 30 metres had increased tremendously, and two individuals were taken on the surface; at dawn they were still present in fair numbers at 30 metres, but by 9 a.m. they had resumed their daytime distribution (Fig. 5). On this occasion then Leptomysis, which normally lives in the water layer contiguous with the bottom by day, did not rise in large numbers much above 20 metres from the bottom.

\begin{tabular}{|c|c|c|c|c|c|}
\hline & Dasymy & LONGIC & IS (Milne & EDWARDS). & \\
\hline & $\begin{array}{l}\text { 1st Series. } \\
3.25 \text { p.m. to } \\
4.45 \text { p.m. }\end{array}$ & $\begin{array}{l}\text { 2nd Series. } \\
7.55 \text { p.m. to } \\
9.17 \text { p.m. }\end{array}$ & $\begin{array}{l}\text { 3rd Series. } \\
10.50 \text { p.m. to } \\
12.20 \text { a.m. }\end{array}$ & $\begin{array}{l}\text { 4th Series. } \\
2.50 \mathrm{a} . \mathrm{m} \text {. to } \\
4.16 \mathrm{a} . \mathrm{m} \text {. }\end{array}$ & $\begin{array}{l}\text { 5th Series. } \\
8.45 \text { a.m. to } \\
10.11 \text { a.m. }\end{array}$ \\
\hline Surface & - & - & - & - & - \\
\hline II $2-7 \mathrm{~m}$. & - & 一 & 一 & 一 & 一 \\
\hline III $9-15 \mathrm{~m}$. & 一 & - & 5 & - & 一 \\
\hline IV $16-20 \mathrm{~m}$ & n. & 一 & 22 & - & 一 \\
\hline $\mathrm{V} \quad 30-34 \mathrm{~m}$. & $\mathrm{n}$. & 1 & 93 & 59 & 1 \\
\hline
\end{tabular}

Although taken in smaller numbers than Leptomysis this species shows essentially the same behaviour.

SchISTOMYSIS SP.

This species shows the same behaviour as Leptomysis; that is, if the numbers taken are indicative of its rarity compared with Leptomysis gracilis. It may, of course, mean that this species as also Erythriops and Haplostylus did not ascend so high in the water as Leptomysis, and that if a deeper haul had been taken much larger numbers would have been caught.

It was not captured at any of the levels in the 1st, 2nd, and 5th series. At 11 p.m. 3 were taken at 20 metres and 27 at 32 metres. At 3 a.m. only 6 were caught at 30 metres and none at the other levels.

\section{ERYthrops SP.}

Only 3 individuals of this species were taken, 1 at 20 metres at 11.15 p.m. and 2 at 32 metres at 11 p.m. They were absent in all the day hauls, at dusk and at dawn.

\section{Haplostylus Normani G. O. Sars.}

This Mysid was only taken in very small numbers : it was absent in all hauls except those at 11, 20, and 32 metres at 11 p.m., when the numbers caught were 1,2 , and 6 respectively, and at 30 metres at 3 a.m., when 9 individuals were caught. It would appear that their behaviour was very similar to that of Leptomysis gracilis. 


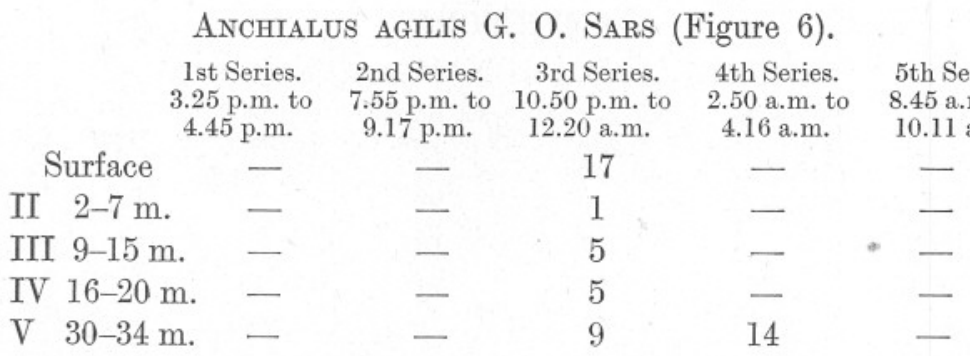

Unlike the other Mysids, which never rose much above 20 metres from the bottom, this form exhibited a very sudden migration towards midnight right to the surface; by 3 a.m. it was only taken at 30 metres (Fig. 6).

\section{CUMACEA.}

Diastylis sp. (Figure 5).

\begin{tabular}{|c|c|c|c|c|c|}
\hline & $\begin{array}{l}\text { lst Series. } \\
.25 \text { p.m. to } \\
4.45 \text { p.m. }\end{array}$ & $\begin{array}{l}\text { 2nd Series. } \\
7.55 \text { p.m. to } \\
9.17 \text { p.m. }\end{array}$ & $\begin{array}{l}\text { 3rd Series. } \\
10.50 \text { p.m. to } \\
12.20 \text { a.m. }\end{array}$ & $\begin{array}{l}\text { 4th Series. } \\
2.50 \text { a.m. to } \\
4.16 \text { a.m. }\end{array}$ & $\begin{array}{l}5 \text { th Series. } \\
8.45 \text { a.m. to } \\
10.11 \text { a.m. }\end{array}$ \\
\hline Surface & - & - & - & - & - \\
\hline II $2-7 \mathrm{~m}$. & - & - & - & 一 & 一 \\
\hline III $9-15 \mathrm{~m}$. & 一 & - - & 1 & - & - \\
\hline IV $16-20 \mathrm{~m}$. & - & 一 & 1 & 1 & 一 \\
\hline $\mathrm{V} \quad 30-34 \mathrm{~m}$. & - & - & 58 & 14 & - \\
\hline
\end{tabular}

This species was absent in all hauls in the 1st, 2nd, and 5th series : at 11 p.m. it was fairly abundant at $30 \mathrm{~m}$., and in smaller numbers at 3 a.m. ; but only 3 specimens were captured above this level (Fig. 5).

Sars (15) remarks that "the Cumacea are . . . on the whole, true bottom forms, though the more agile males of some species may be found at times swarming near the surface, especially at night." It is interesting to note that on this occasion the majority of this species taken 20 metres above the bottom were females.

\begin{tabular}{|c|c|c|c|c|c|}
\hline \multicolumn{6}{|c|}{ Cumaceans (sp. indetermined). } \\
\hline & $\begin{array}{l}\text { 1st Series. } \\
3.25 \text { p.m. to } \\
4.45 \text { p.m. }\end{array}$ & $\begin{array}{l}\text { 2nd Series. } \\
7.55 \text { p.m. to } \\
9.17 \text { p.m. }\end{array}$ & $\begin{array}{l}\text { 3rd Series. } \\
10.50 \text { p.m. to } \\
12.20 \text { a.m. }\end{array}$ & $\begin{array}{l}\text { 4th Series. } \\
2.50 \text { a.m. to } \\
4.16 \mathrm{a} . \mathrm{m} \text {. }\end{array}$ & $\begin{array}{l}\text { 5th Series. } \\
8.45 \text { a.m. to } \\
10.11 \text { a.m. }\end{array}$ \\
\hline Surface & - & 1 & - & - & - \\
\hline II $2-7 \mathrm{~m}$. & - & - & 2 & 一 & 一 \\
\hline III $9-15 \mathrm{~m}$. & - & 一 & 1 & 1 & - \\
\hline IV $16-20 \mathrm{~m}$ & - & - & 一 & 4 & - \\
\hline $\mathrm{V} \quad 30-34 \mathrm{~m}$ & 一 & - & 9 & 25 & - \\
\hline
\end{tabular}

Time would not admit of the identification of these Cumaceans, which probably consist of Bodotrius sp. and Pseudocuma sp. These appeared at 30 metres, and above, only in the dark hours. 


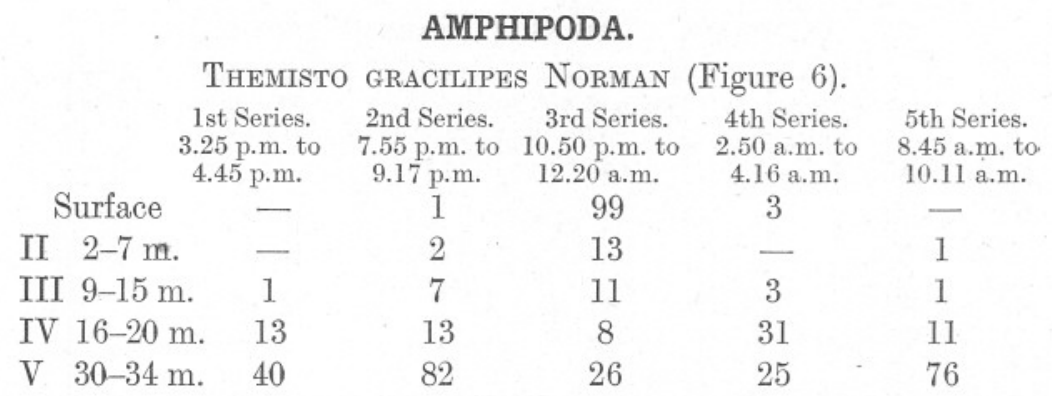

There are several observations on the occurrence of this species at the surface at night, which appears to be a common characteristic of the genus.

This series shows a region of greatest abundance in the daytime below a depth of $20 \mathrm{~m}$. and a marked migration to the surface at midnight (Fig. 6).

This agrees with Stephensen's findings from the material collected in the Atlantic on the Danish Expedition, 1908-10 (1\%). He says : "During the night the species was only taken close to the surface (at most $25 \mathrm{~m}$. w.), during the day almost exclusively with $65-100 \mathrm{~m}$. w."

\begin{tabular}{cccccc}
\multicolumn{7}{c}{ APHERUSA sP. } \\
& 1st Series. & 2nd Series. & 3rd Series. & 4th Series. & 5th Series. \\
& 3.25 p.m. to & 7.55 p.m.to & 10.50 p.m. to & 2.50 a.m. to & 8.45 a.m. to. \\
& 4.45 p.m. & 9.17 p.m. & 12.20 a.m. & 4.16 a.m. & 10.11 a.m. \\
Surface & 7 & 4 & - & 4 & 20 \\
& $1 \cdot 2 \%$ & $0 \cdot 8 \%$ & $0 \cdot 0 \%$ & $1 \cdot 1 \%$ & $3 \cdot 2 \%$ \\
II & 5 & 11 & 70 & 2 & 10 \\
2-7 m. & $0 \cdot 9 \%$ & $2 \cdot 1 \%$ & $7 \cdot 8 \%$ & $0 \cdot 6 \%$ & $1 \cdot 6 \%$ \\
III & 74 & 40 & 70 & 70 & 80 \\
9-15 m. & $12 \cdot 8 \%$ & $7 \cdot 8 \%$ & $7 \cdot 8 \%$ & $19 \cdot 7 \%$ & $12 \cdot 6 \%$ \\
IV & 290 & 200 & 260 & 140 & 210 \\
16-20 m. & $50 \cdot 4 \%$ & $38 \cdot 8 \%$ & $29 \cdot 1 \%$ & $39 \cdot 3 \%$ & $33 \cdot 3 \%$ \\
V & 200 & 260 & 494 & 140 & 310 \\
$30-34 \mathrm{~m}$. & $34 \cdot 7 \%$ & $50 \cdot 5 \%$ & $55 \cdot 3 \%$ & $39 \cdot 3 \%$ & $49 \cdot 3 \%$
\end{tabular}

These amphipods, consisting probably chiefly of Apherusa clevii G. O. Sars, exhibited no marked movement at night, being present in greatest abundance below 15 metres in all the five series of hauls. If anything there is a slight tendency to rise at midnight, but the numbers are not conclusive.

\section{UROTHӧ̈ SP.}

This amphipod, which in the daytime adopts a benthic habit, showed a remarkably sudden migration to the surface at 9 p.m. when 40 were captured; at midnight there were still 2 at the surface and 2 at 30 metres, but they were absent in all the remaining hauls. None were taken in the daytime or at dawn. 
Mixed Amphipods (sp. undetermined).

At midnight and dawn a number of bottom living amphipods were taken in the lower layers. At 11 p.m. 11 were taken at 20 metres, and 27 at 32 metres ; but at 3 a.m., while 19 were caught at 30 metres, only a single individual occurred at 18 metres.

Time would not allow of the identification of these forms, but there were present probably at least 7 or 8 species, amongst which were recognised Monoculodes sp., Bathyporeia sp., and Ampeliscus sp., all true bottom-living forms in the daytime.

\section{DECAPODA.}

LEANDER SP. LARVA.

\begin{tabular}{|c|c|c|c|c|c|}
\hline & $\begin{array}{l}\text { 1st Series. } \\
.25 \text { p.m. to } \\
4.45 \text { p.m. }\end{array}$ & $\begin{array}{l}\text { 2nd Series. } \\
7.55 \text { p.m. to } \\
9.17 \text { p.m. }\end{array}$ & $\begin{array}{l}\text { 3rd Series. } \\
10.50 \text { p.m. to } \\
12.20 \text { a.m. }\end{array}$ & $\begin{array}{l}\text { 4th Series. } \\
2.50 \text { p.m. to } \\
4.16 \mathrm{a} . \mathrm{m} .\end{array}$ & $\begin{array}{l}5 \text { th Series. } \\
8.45 \text { a.m. to } \\
10.11 \text { a.m. }\end{array}$ \\
\hline Surface & $8 \dagger$ & $9 \dagger$ & 10 & $9 \dagger$ & $11 \uparrow$ \\
\hline II $2-7 \mathrm{~m}$. & $6 \uparrow$ & 10 & 10 & $10 \dagger$ & 2 \\
\hline III $9-15 \mathrm{~m}$. & $3 \uparrow$ & 40 & 一 & 10 & 一 \\
\hline IV $16-20 \mathrm{~m}$. & - & - & 10 & 10 & 10 \\
\hline $\mathrm{V} \quad 30-34 \mathrm{~m}$. & - & - & - & - & - \\
\hline
\end{tabular}

$\uparrow$ Denotes that a complete count was made, the remaining figures were obtained by sampling only.

These larvæ, which probably consist of both Leander serratus and L. squilla, were mostly of Stage V in development, that is the last larval stage before the first post-larvæ. They were noteworthy for being present in greater abundance on the surface layers than in the deeper water both in the daytime and at night: in this type of distribution they differed from all other decapod larvæ present in the collection.

Pandalid sp. and Processa canaliculata larve (Figure 4).

\begin{tabular}{|c|c|c|c|c|c|}
\hline & $\begin{array}{l}\text { 1st Series. } \\
3.25 \text { p.m. to } \\
4.45 \text { p.m. }\end{array}$ & $\begin{array}{l}\text { 2nd Series. } \\
7.55 \text { p.m. to } \\
9.17 \text { p.m. }\end{array}$ & $\begin{array}{l}\text { 3rd Series. } \\
10.50 \text { p.m. to } \\
12.20 \text { a.m. }\end{array}$ & $\begin{array}{l}\text { 4th Series. } \\
2.50 \text { a.m. to } \\
4.16 \text { a.m. }\end{array}$ & $\begin{array}{l}\text { 5th Series. } \\
8.45 \text { a.m. to } \\
10.11 \text { a.m. }\end{array}$ \\
\hline \multirow[t]{2}{*}{ Surface } & 11 & 4 & 2 & 1 & 1 \\
\hline & $0 \cdot 4 \%$ & $0.2 \%$ & $0.1 \%$ & $0 \cdot 1 \%$ & $0.1 \%$ \\
\hline II & 87 & 20 & 180 & 1 & 20 \\
\hline $2-7 \mathrm{~m}$. & $3.2 \%$ & $1 \%$ & $12.7 \%$ & $0 \cdot 1 \%$ & $1.3 \%$ \\
\hline III & 922 & 390 & 280 & 110 & 300 \\
\hline $9-15 \mathrm{~m}$ & $33.5 \%$ & $20 \%$ & $19 \cdot 7 \%$ & $7.5 \%$ & $20 \cdot 3 \%$ \\
\hline IV & 1440 & 490 & 510 & 630 & 490 \\
\hline $16-20 \mathrm{~m}$. & $52 \cdot 4 \%$ & $25 \cdot 1 \%$ & $35.8 \%$ & $43 \cdot 1 \%$ & $33 \cdot 1 \%$ \\
\hline V & 290 & 1050 & 451 & 720 & 670 \\
\hline $30-34 \mathrm{~m}$. & $10.5 \%$ & $53 \cdot 7 \%$ & $31 \cdot 7 \%$ & $49 \cdot 2 \%$ & $45 \cdot 2 \%$ \\
\hline
\end{tabular}


There are the larvæ of at least four species present in these samples. The majority are larvæ of Pandalina brevirostris; the other species are Pandalus borealis, Processa canaliculata, and Spirontocaris sp.

While Processa canaliculata is not classified at present as being a Pandalid, the larva as pointed out by Gurney (5) is almost indistinguishable from that of Pandalus. I have examined carefully twelve of the samples with the following results :-

\section{1st Series.}

III. Pandalid sp. 883, Processa canaliculata 27, Spirontocaris sp. 12

V $\quad$, $\quad, 240 \quad, \quad 2 \quad, \quad 40 \quad 40$

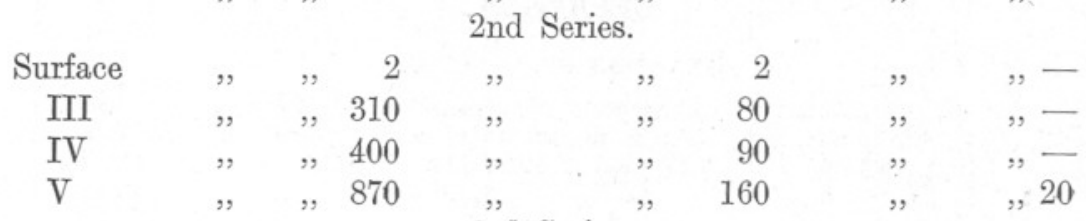

$\begin{array}{cccrccccc}\text { Surface } & , & , & 2 & \text { 3rd Series. } & , & - & , & \text { sp. - } \\ \text { III } & , & , & 250 & , & , & 30 & , & ,- \\ \text { V } & " & , & 391 & , & , & 60 & , & ,-\end{array}$

$\begin{array}{ccrrrrrrr}\text { Surface } & , & , & 1 & , & , & - & , & ,- \\ \text { III } & , & , & 110 & , & , & - & , & ,- \\ \text { V } & , & , & 640 & , & , & 80 & , & ,-\end{array}$

It would seem from these results that the distribution of Processa is probably not unlike that of Pandalus sp. Spirontocaris larvæ are present in too small numbers to be significant.

Fig. 4 illustrates that these forms did not on this occasion show any marked change in their distribution through the period from daylight to daylight. There is perhaps a slight tendency to rise at midnight, but the larvæ never appeared in numbers in the surface layers. They were present always in largest numbers below 7 metres.

\section{Crangonid post-larve (Figure 5).}

\begin{tabular}{|c|c|c|c|c|c|}
\hline & $\begin{array}{l}\text { 1st Series. } \\
3.25 \text { p.m. to } \\
4.45 \text { p.m. }\end{array}$ & $\begin{array}{l}\text { 2nd Series. } \\
7.55 \text { p.m. to } \\
9.17 \text { p.m. }\end{array}$ & $\begin{array}{l}\text { 3rd Series. } \\
10.50 \text { p.m. to } \\
12.20 \text { a.m. }\end{array}$ & $\begin{array}{l}\text { 4th Series. } \\
2.50 \text { a.m. to } \\
4.16 \text { a.m. }\end{array}$ & $\begin{array}{l}\text { 5th Series. } \\
8.45 \text { a.m. to } \\
10.11 \text { a.m. }\end{array}$ \\
\hline Surface & - & 1 & 20 & - & - \\
\hline II $2-7 \mathrm{~m}$. & - & 20 & 20 & - & 10 \\
\hline III $9-15 \mathrm{~m}$. & 10 & 70 & 50 & - & 70 \\
\hline IV $16-20 \mathrm{~m}$ & 285 & 100 & 440 & 20 & 150 \\
\hline $\mathrm{V} \quad 30-34 \mathrm{~m}$ & 120 & 140 & 973 & 1020 & 130 \\
\hline
\end{tabular}


There are a few larval stages among these, but by far the majority were post-larvæ. This àccounts probably for their vertical distribution, which was typical of $\mathrm{m}$ ny benthic forms, seeing that at this stage they must be seeking the bottom.

Their behaviour was exactly similar to that of the Mysids; in the daytime they were taken only in small numbers in the lower layers, but at 11 p.m. and 3 a.m. they were caught at 30 metres in large numbers (Fig. 5).

\section{Palinurus Phyllosoma.}

\begin{tabular}{|c|c|c|c|c|c|}
\hline $\begin{array}{r}1 \\
3.2 \\
4\end{array}$ & $\begin{array}{l}\text { 1st Series. } \\
.25 \text { p.m. to } \\
4.45 \text { p.m. }\end{array}$ & $\begin{array}{l}\text { 2nd Series. } \\
7.55 \text { p.m. to } \\
9.17 \text { p.m. }\end{array}$ & $\begin{array}{l}\text { 3rd Series. } \\
10.50 \text { p.m. to } \\
12.20 \text { a.m. }\end{array}$ & $\begin{array}{l}\text { 4th Series. } \\
2.50 \text { a.m. to } \\
4.16 \text { a.m. }\end{array}$ & $\begin{array}{l}\text { 5th Series. } \\
8.45 \text { a.m. to } \\
10.11 \text { a.m. }\end{array}$ \\
\hline Surface & - & 18 & - & 4 & - \\
\hline II $2-7 \mathrm{~m}$. & 1 & 30 & - & 5 & 一 \\
\hline III $9-15 \mathrm{~m}$. & 一 & 20 & - & 30 & 一 \\
\hline IV $16-20 \mathrm{~m}$. & 15 & 10 & - & 20 & 30 \\
\hline $\mathrm{V} \quad 30-34 \mathrm{~m}$. & 一 & 10 & - & 20 & 30 \\
\hline
\end{tabular}

The phyllosoma larva of the Rock Lobster was present in the daytime in greatest numbers below 12 metres : at 8-9 p.m. it was taken in all layers from 30 metres to the surface, but was most abundant in the upper layers: at midnight none were captured, so that we have no evidence as to the midnight vertical distribution. At 4 a.m. the majority had returned to below 2 metres.

Galatheid LaRve (Figure 4).

\begin{tabular}{|c|c|c|c|c|c|}
\hline & $\begin{array}{l}\text { lst Series. } \\
3.25 \text { p.m. to } \\
4.45 \text { p.m. }\end{array}$ & $\begin{array}{l}\text { 2nd Series. } \\
7.55 \text { p.m. to } \\
9.17 \text { p.m. }\end{array}$ & $\begin{array}{l}\text { 3rd Series. } \\
10.50 \text { p.m. to } \\
12.20 \text { a.m. }\end{array}$ & $\begin{array}{l}\text { 4th Series. } \\
2.50 \text { p.m. to } \\
4.16 \text { a.m. }\end{array}$ & $\begin{array}{l}\text { 5th Series.' } \\
8.45 \text { a.m. to } \\
10.11 \text { a.m. }\end{array}$ \\
\hline Surface & 15 & 191 & 240 & 4 & 10 \\
\hline & $0.3 \%$ & $2.7 \%$ & $3.6 \%$ & $0 \cdot 1 \%$ & $0.1 \%$ \\
\hline II & 24 & 800 & 870 & 42 & 130 \\
\hline $2-7 \mathrm{~m}$. & $0 \cdot 4 \%$ & $11.5 \%$ & $13 \cdot 1 \%$ & $0.9 \%$ & $1.5 \%$ \\
\hline III & 961 & 1390 & 2060 & 630 & 1570 \\
\hline $9-15 \mathrm{~m}$ & $16 \cdot 4 \%$ & $19.9 \%$ & $30.9 \%$ & $14 \cdot \% \%$ & $18 \cdot \% \%$ \\
\hline IV & 3430 & $2000^{\circ}$ & 1470 & 1520 & 3490 \\
\hline $16-20 \mathrm{~m}$. & $58.5 \%$ & $28.7 \%$ & $22 \cdot 1 \%$ & $35 \cdot 4 \%$ & $41.5 \%$ \\
\hline $\mathrm{V}$ & 1430 & 2600 & 2020 & 2100 & 3210 \\
\hline 30-34 m. & $24 \cdot 4 \%$ & $3 \% \cdot 2 \%$ & $30 \cdot 3 \%$ & $48.9 \%$ & $38 \cdot 2 \%$ \\
\hline
\end{tabular}

These larvæ were present in greatest numbers below 12 metres in the daytime: at dusk and at midnight they tended to become more evenly distributed from the upper layers downwards, but were at no time very abundant on the surface; although the actual numbers captured give one the idea that they come to the surface in quantities at night, if we 
examine the percentages we see that this is quite an insignificant movement.

In fact, these larvæ appeared to behave in a very similar manner to both Pandalus larvæ and Enpagurus larvæ, exhibiting no very marked changes in vertical distribution through the dark hours (Fig. 4).

With this form an attempt was made to determine whether there was any difference in distribution with age. The larvæ were accordingly separated into those stages without uropods, Group A, and those in which uropods were present, Group B. The results are set out in the two accompanying tables, and show that there was on this occasion a marked tendency for the earlier larval stages to have their region of maximum abundance slightly higher than that of the later stages.

\begin{tabular}{|c|c|c|c|c|c|}
\hline & & oup $A: w$ & hout urope & & \\
\hline & 1st Series. & 2nd Series. & 3rd Series. & 4th Series. & 5th Series. \\
\hline Surface & - & 70 & 110 & - & 10 \\
\hline & $0 \%$ & $3.8 \%$ & $15 ; 2 \%$ & $0 \%$ & $0 \cdot 4 \%$ \\
\hline II & 4 & 320 & 60 & 4 & 60 \\
\hline & $0.3 \%$ & $17.8 \%$ & $8.3 \%$ & $0.5 \%$ & $2 \%$ \\
\hline III & 290 & 380 & 310 & 150 & 1070 \\
\hline & $24 \cdot 8 \%$ & $21 \cdot 2 \%$ & $42.9 \%$ & $21 \%$ & $36.7 \%$ \\
\hline IV & 670 & 750 & 130 & 250 & 1450 \\
\hline & $5 \% \cdot 6 \%$ & $41 \cdot 6 \%$ & $18 \%$ & $35 \%$ & $49 \cdot 6 \%$ \\
\hline V & 200 & 280 & 114 & 310 & 330 \\
\hline & $17 \cdot 2 \%$ & $15 \cdot 6 \%$ & $15 \cdot 6 \%$ & $43.5 \%$ & $11.3 \%$ \\
\hline & & Group B: & th uropods & & \\
\hline Surface & $\begin{array}{c}\text { 1st Series. } \\
15\end{array}$ & $\begin{array}{c}\text { 2nd Series. } \\
121\end{array}$ & $\begin{array}{c}\text { 3rd Series. } \\
230\end{array}$ & $\begin{array}{c}\text { 4th Series. } \\
4\end{array}$ & 5th Series. \\
\hline & $0.3 \%$ & $2.3 \%$ & $3 \cdot 8 \%$ & $0 \cdot 1 \%$. & $0 \%$ \\
\hline II & 20 & 480 & 810 & 38 & 70 \\
\hline & $0 \cdot 4 \%$ & $9.3 \%$ & $13 \cdot 4 \%$ & $1 \cdot 1 \%$ & $1.3 \%$ \\
\hline III & 673 & 1010 & 1750 & 480 & 550 \\
\hline & $14.3 \%$ & $19.5 \%$ & $29 \%$ & $13 \cdot 4 \%$ & $9.9 \%$ \\
\hline IV & 2760 & 1250 & 1340 & 1270 & 2040 \\
\hline & $58.8 \%$ & $24 \cdot 1 \%$ & $22 \cdot 2 \%$ & $35.5 \%$ & $36 \cdot 8 \%$ \\
\hline V & 1230 & 2320 & 1910 & 1790 & 2880 \\
\hline & $26 \cdot 2 \%$ & $44 \cdot 8 \%$ & $31 \cdot 6 \%$ & $49.9 \%$ & $52 \%$ \\
\hline
\end{tabular}

For instance, in the three lower levels the daytime abundance of Group A, early stages, went $24 \cdot 8 \%, 57 \cdot 6 \%$, and $17 \cdot 2 \%$, and $36 \cdot 7 \%$, $49 \cdot 6 \%$, and $11 \cdot 3 \%$, while that of Group B was $14,3 \%, 58 \cdot 8 \%$, and $26 \cdot 2 \%$, and $9.9 \%, 36 \cdot 8 \%$, and $52 \%$ respectively. In each case the early larval stages show a bias on the side above the level of maximum abundance, 
whereas the later stages show the opposite distribution. Further at midnight the early larval stages show quite a marked tendency to move into the surface layers.

\begin{tabular}{|c|c|c|c|c|c|}
\hline Surface & $\begin{array}{l}1 \text { st Series. } \\
.25 \text { p.m. to } \\
4.45 \text { p.m. } \\
\text { _ }\end{array}$ & $\begin{array}{c}\text { 2nd Series. } \\
7.55 \text { p.m. to } \\
9.17 \text { p.m. } \\
20\end{array}$ & $\begin{array}{l}\text { 3rd Series. } \\
10.50 \text { p.m. to } \\
12.20 \text { a.m. } \\
40\end{array}$ & $\begin{array}{l}\text { 4th Series. } \\
2.50 \text { a.m. to } \\
4.16 \text { a.m. } \\
\text { - }\end{array}$ & $\begin{array}{l}\text { 5th Series. } \\
8.45 \text { a.m. to } \\
10.11 \text { a.m. } \\
\end{array}$ \\
\hline II $2-7 \mathrm{~m}$. & - & - & 60 & - & - \\
\hline III $9-15 \mathrm{~m}$. & 6 & 30 & 110 & 10 & 10 \\
\hline IV $16-20 \mathrm{~m}$. & 45 & 50 & 240 & 90 & 40 \\
\hline $\mathrm{V} \quad 30-34 \mathrm{~m}$. & 10 & 10 & 470 & 550 & 80 \\
\hline
\end{tabular}

From the figures obtained it would seem very probable that in the daytime and at dusk these late stages of the young Galathea had their region of maximum abundance somewhere below the greatest depth sampled, 34 metres ; at 11 p.m., however, they appeared in large numbers at 30 metres, and were present in diminishing numbers right to the surface at midnight : at 4 a.m. they had retired from the surface, but were still very abundant at 30 metres. In this distribution the Galathea showed exactly similar diurnal vertical movements to those shown by the benthic forms like Mysids and Cumacea (Fig. 5).

It appears from these observations on the various stages in the development of Galathea that there is a gradual sinking of the region of maximum abundance as we pass from the earliest stages to the latest and finally the adult bottom living form. It is most probable that this holds good for many other forms of decapod larvæ at this time of year.

Porcelilana sp. Zoea (Figure 3).

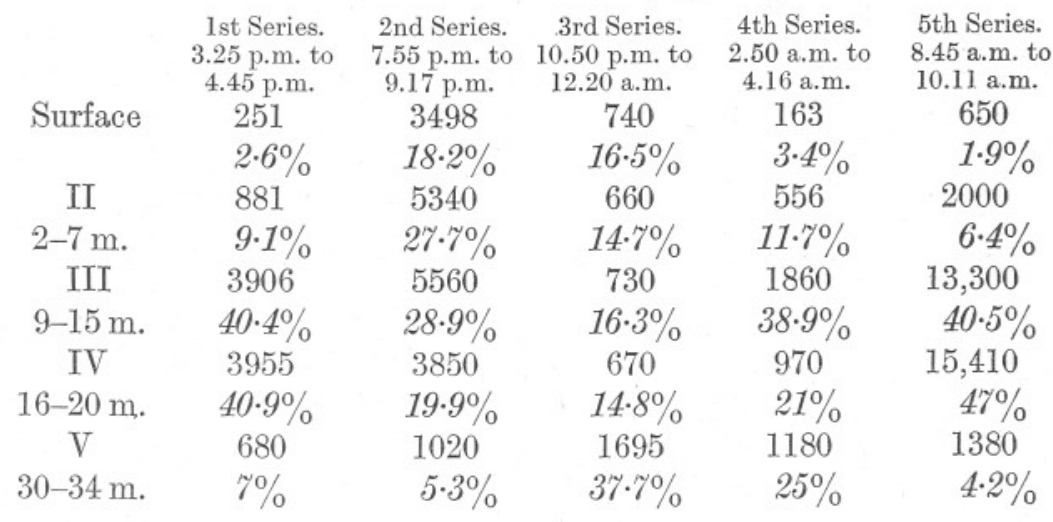

From a region of maximum abundance between 10 and 30 metres in the daytime these larvæ had spread out by 9.30 p.m. into all layers, and NEW SERIES. - VoL. XIII. No. 4. oCTOBER, 1925. 
were still distributed in this manner at midnight. By 3.30 a.m. they had deserted the upper 5 metres, and by 9 a.m. the region of greatest abundance was again below 10 metres (Fig. 3).

Larva of Callianassa subterranea Leach (Figure 2).

$\begin{array}{cccccc} & \text { 1st Series. } & \text { 2nd Series. } & \text { 3rd Series. } & \text { 4th Series. } & 5 \text { th Series. } \\ & 3.25 \text { p.m. to } & 7.55 \text { p.m. to } & 10.50 \text { p.m. to } & 2.50 \text { a.m. to } & 8.45 \text { a.m. to } \\ \text { Surface } & 4.45 \text { p.m. } & 9.17 \text { p.m. } & 12.20 \text { a.m. } & 4.16 \text { a.m. } & 10.11 \text { a.m. } \\ & 1 & 110 & 510 & 10 & - \\ \text { II } & 0 \cdot 3 \% & 18 \% & 37 \cdot 8 \% & 0 \cdot 5 \% & 0 \cdot 0 \% \\ \text { 2-7 m. } & 17 & 210 & 290 & 467 & 110 \\ \text { III } & 4 \cdot 3 \% & 34 \cdot 5 \% & 21 \cdot 5 \% & 26 \cdot 3 \% & 17 \cdot 5 \% \\ \text { 9-15 m. } & 105 & 70 & 100 & 830 & 270 \\ \text { IV } & 26 \cdot \% \% & 11 \cdot 5 \% & 7 \cdot 4 \% & 46 \cdot 7 \% & 42 \cdot 8 \% \\ \text { 16-20 m. } & 56 \% & 110 & 300 & 240 & 140 \\ \text { V } & 50 & 18 \% & 22 \cdot 2 \% & 13 \cdot 5 \% & 22 \cdot 2 \% \\ 30-34 \text { m. } & 12 \cdot 7 \% & 110 & 130 & 230 & 110 \\ & & 18 \% & 11 \cdot 7 \% & 13 \% & 17 \cdot 5 \%\end{array}$

In their behaviour these larvæ were very similar to those of Upogebia, showing a definite migration to the surface, and being taken there in greatest quantities at midnight. At 4 a.m. they had left the surface, and their maximum abundance was at a depth of 9 metres (Fig. 2).

\section{UPOGEBia LARve (Figure 2).}

$\begin{array}{cccccc} & \text { 1st Series. } & \text { 2nd Series. } & \text { 3rd Series. } & \text { 4th Series. } & \text { 5th Series. } \\ & 3.25 \text { p.m. to } & 7.55 \text { p.m. to } & 10.50 \text { p.m. to } & 2.50 \text { a.m. to } & 8.45 \text { a.m. to } \\ & 4.45 \text { p.m. } & 9.17 \text { p.m. } & 12.20 \text { a.m. } & 4.16 \text { a.m. } & 10.11 \text { a.m. } \\ \text { Surface } & 14 & 659 & 2010 & 8 & 27 \\ & 0 \cdot 7 \% & 12 \cdot 1 \% & 50 \cdot 5 \% & 0 \cdot 5 \% & 0 \cdot 9 \% \\ \text { II } & 78 & 880 & 830 & 131 & 170 \\ 2-7 \text { m. } & 3 \cdot 7 \% & 16 \cdot 1 \% & 20 \cdot 9 \% & 7 \cdot 7 \% & 5 \cdot 6 \% \\ \text { III } & 897 & 1270 & 320 & 750 & 690 \\ \text { 9-15 m. } & 42 \cdot 9 \% & 23 \cdot 2 \% & 8 \% & 44 \cdot 1 \% & 22 \cdot 6 \% \\ \text { IV } & 950 & 1610 & 410 & 470 & 1150 \\ 16-20 \text { m. } & 45 \cdot 5 \% & 29 \cdot 4 \% & 10 \cdot 3 \% & 27 \cdot 7 \% & 37 \cdot 6 \% \\ \text { V } & 150 & 1050 & 408 & 340 & 1020 \\ 30-34 \mathrm{~m} . & 7 \cdot 2 \% & 19 \cdot 2 \% & 10 \cdot 3 \% & 20 \% & 33 \cdot 3 \%\end{array}$

In the daytime these larvæ were present in greatest numbers in the hauls from 13 metres down. By 9 p.m. they were present in all layers from the surface to 30 metres. At midnight by far the majority were taken on the surface indicating that a definite migration had taken place into this region from the lower layers. At 4 a.m. they had left the surface, and were caught chiefly at 9 metres and below, and by $10 \mathrm{a.m}$. the region of maximum abundance was again below 13 metres (Fig. 2). 


\section{UPOGEBIA POST-LARVA.}

$\begin{array}{lccccc} & \text { 1st Series. } & \text { 2nd Series. } & \text { 3rd Series. } & \text { 4th Series. } & \text { 5th Series. } \\ & \text { 3.25 p.m. to } & 7.55 \text { p.m. to } & 10.50 \text { p.m. to } & 2.50 \text { a.m. to } & 8.45 \text { a.m. to } \\ \text { 4.45 p.m. } & 9.17 \text { p.m. } & 12.20 \text { a.m. } & 4.16 \text { a.m. } & 10.11 \text { a.m. } \\ \text { Surface } & - & 3 & 20 & - & - \\ \text { II } 2-7 \mathrm{~m} . & - & - & 20 & 1 & - \\ \text { III } 9-15 \mathrm{~m} . & - & - & 10 & - & - \\ \text { IV } 16-20 \mathrm{~m} . & - & - & 30 & 20 & - \\ \text { V } 30-34 \mathrm{~m} . & - & 10 & 60 & 90 & -\end{array}$

The post-larvæ of Gebia exhibit the typical behaviour shown by most of the organisms living on or very near the bottom in the daytime. They were absent in all the day hauls. At 9 p.m. three were taken right at the surface : by midnight they were present at all depths, but the majority were captured at 30 metres. At dawn they had again left the upper layers, but were still present in large numbers at 30 metres.

\begin{tabular}{|c|c|c|c|c|c|}
\hline \multicolumn{6}{|c|}{ PAGURID LARVA (Figure 4). } \\
\hline Surface & $\begin{array}{c}\text { 1st Series. } \\
3.25 \text { p.m. to } \\
4.45 \text { p.m. } \\
1 \\
0.2 \%\end{array}$ & $\begin{array}{c}\text { 2nd Series. } \\
7.55 \text { p.m. to } \\
9.17 \text { p.m. } \\
18 \\
1.2 \%\end{array}$ & $\begin{array}{c}\text { 3rd Series. } \\
10.50 \text { p.m. to } \\
12.20 \text { a.m. } \\
4 \\
0.4 \%\end{array}$ & $\begin{array}{c}\text { 4th Series. } \\
2.50 \text { a.m. to } \\
4.16 \text { a.m. } \\
1 \\
0 \cdot 1 \%\end{array}$ & $\begin{array}{c}\text { 5th Series. } \\
8.45 \text { a.m. to } \\
10.11 \text { a.m. } \\
\text { - } \\
0.0 \%\end{array}$ \\
\hline II & 4 & 100 & 50 & 10 & - \\
\hline $2-7 \mathrm{~m}$. & $0.7 \%$ & $6.5 \%$ & $5 \cdot 6 \%$ & $0.9 \%$ & $0.0 \%$ \\
\hline III & $84^{\prime}$ & 340 & 190 & 150 & 40 \\
\hline 9-15 m. & $14.5 \%$ & $22.3 \%$ & $21 \cdot 3 \%$ & $14 \cdot 3 \%$ & $6.6 \%$ \\
\hline IV & 200 & 470 & 290 & 420 & 200 \\
\hline $16-20 \mathrm{~m}$. & $34.5 \%$ & $30 \cdot 7 \%$ & $32 \cdot 4 \%$ & $40 \%$ & $32.8 \%$ \\
\hline $\mathrm{V}$ & 290 & 600 & 314 & 470 & 370 \\
\hline $30-34 \mathrm{~m}$. & $50 \cdot 1 \%$ & $39 \cdot 3 \%$ & $40 \cdot 3 \%$ & $44 \cdot \% \%$ & $60 \cdot 6 \%$ \\
\hline
\end{tabular}

These larvæ showed very little change in their vertical distribution during the dark hours. There is a very slight rise at midnight, but no increase in numbers at the surface. Whereas in the daytime the greatest numbers were taken at 18 metres, and below, at midnight the upper limit is slightly higher at about 12 metres, as shown by Fig. 4, but it seems hardly sufficient to be significant.

\begin{tabular}{|c|c|c|c|c|c|}
\hline & & Eupagurus & GLAUCOTH & & \\
\hline & $\begin{array}{l}\text { 1st Series. } \\
25 \text { p.m. to } \\
4.45 \text { p.m. }\end{array}$ & $\begin{array}{l}\text { 2nd Series. } \\
7.55 \text { p.m. to } \\
9.17 \text { p.m. }\end{array}$ & $\begin{array}{l}\text { 3rd Series. } \\
10.50 \mathrm{p} . . \mathrm{m} \text { to } \\
12.20 \mathrm{a} . \mathrm{m} .\end{array}$ & $\begin{array}{l}\text { 4th Series. } \\
2.50 \text { a.m. to } \\
4.16 \text { a.m. }\end{array}$ & $\begin{array}{l}5 \text { th Series. } \\
8.45 \text { a.m. to } \\
10.11 \text { a.m. }\end{array}$ \\
\hline Surface & - & - & 20 & - & - \\
\hline II $2-7 \mathrm{~m}$. & - & - & - & - & 一 \\
\hline III $9-15 \mathrm{~m}$. & 1 & 一 & - & 一 & - \\
\hline IV $16-20 \mathrm{~m}$ & 一 & 一 & 60 & 一 & - \\
\hline V $\quad 30-34 \mathrm{~m}$ & - & - & 90 & 150 & - \\
\hline
\end{tabular}


These late larval stages of Eupagurus occurred in the daytime and at dusk, probably below the deepest haul at 34 metres : at midnight they were taken on the surface, but in greatest numbers at 20 and 30 metres : at 3 a.m. they were only taken at 30 metres.

Jackson (10) remarks: "Like the fresh-water Mysis, they spend the day at the bottom of the sea and rise to the surface at night. It is during this stage that the animal first seeks a moveable residence, and the larvæ spend their time in alternately prowling on the bottom and swimming about."

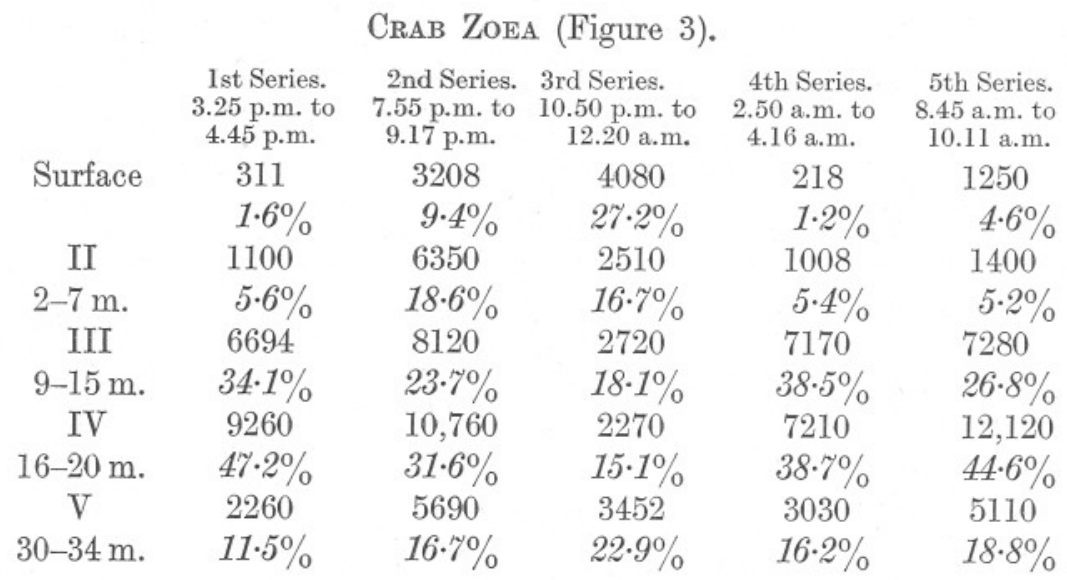

Fig. 3 shows that these crab zoeas (species unknown) showed a very similar behaviour to the zoeas of Porcellana, living in greatest numbers between 10 and 30 metres by day and extending into the upper layers and surface at dusk and midnight.

\begin{tabular}{|c|c|c|c|c|c|}
\hline & $\begin{array}{l}\text { 1st Series. } \\
3.25 \text { p.m. to } \\
4.45 \text { p.m. }\end{array}$ & $\begin{array}{l}\text { 2nd Series. } \\
7.55 \text { p.m. to } \\
9.17 \text { p.m. }\end{array}$ & $\begin{array}{l}\text { 3rd Series. } \\
10.50 \text { p.m. to } \\
12.20 \text { a.m. }\end{array}$ & $\begin{array}{l}\text { 4th Series. } \\
2.50 \text { a.m. to } \\
4.16 \text { a.m. }\end{array}$ & $\begin{array}{l}\text { 5th Series. } \\
8.45 \text { a.m. to } \\
10.11 \text { a.m. }\end{array}$ \\
\hline \multirow[t]{2}{*}{ Surface } & 12 & 12 & 290 & 4 & 62 \\
\hline & $1.2 \%$ & $0.7 \%$ & $30 \cdot 5 \%$ & $0.6 \%$ & $5 \%$ \\
\hline II & 4 & 30 & 110 & 2 & 30 \\
\hline $2-7 \mathrm{~m}$. & $0 \cdot 4$ & $1 . \% \%$ & $17 \cdot 6 \%$ & $0.3 \%$ & $2 \cdot 4 \%$ \\
\hline III & 135 & 150 & 110 & 70 & 130 \\
\hline $9-15 \mathrm{~m}$. & $13 \cdot 4 \%$ & $8.8 \%$ & $11 \cdot 6 \%$ & $10 \cdot 1 \%$ & $10 \cdot 6 \%$ \\
\hline IV & 425 & 370 & 150 & 310 & 230 \\
\hline $16-20 \mathrm{~m}$. & $42 \cdot 2 \%$ & $21 \cdot 6 \%$ & $15 \cdot 8 \%$ & $44.5 \%$ & $18.7 \%$ \\
\hline $\mathrm{V}$ & 430 & 1150 & 290 & 310 & 780 \\
\hline $30-34 \mathrm{~m}$. & $42 \cdot 8 \%$ & $67 \cdot 2 \%$ & $30.5 \%$ & $44.5 \%$ & $63.3 \%$ \\
\hline
\end{tabular}


At midnight these forms appeared on the surface in large numbers, being distributed from top to bottom. At all other times they were present in greatest numbers below 15 metres. This upward spreading must have occurred rapidly, as at 9 p.m. there was no indication of any change in vertical distribution; by dawn the daylight distribution was being resumed (Fig. 6).

\section{MOLLUSCA.}

\section{Larval Gastropods and Limacina retroversa (Flemm.).}

\begin{tabular}{|c|c|c|c|c|c|}
\hline & $\begin{array}{l}\text { ries. } \\
\text { m. to } \\
\text { m. }\end{array}$ & $\begin{array}{l}\text { 2nd Series. } \\
7.55 \text { p.m. to } \\
9.17 \text { p.m. }\end{array}$ & $\begin{array}{l}\text { 3rd Series. } \\
10.50 \text { p.m. to } \\
12.20 \text { a.m. }\end{array}$ & $\begin{array}{l}\text { 4th Series. } \\
2.50 \text { a.m. to } \\
4.16 \text { a.m. }\end{array}$ & $\begin{array}{l}\text { 5th Series. } \\
8.45 \text { a.m. } \\
10.11 \text { a.m. }\end{array}$ \\
\hline Surface & - & 2 & - & 1 & - \\
\hline II $2-7 \mathrm{~m}$. & 19 & 10 & 一 & 12 & 20 \\
\hline III $9-15 \mathrm{~m}$. & 84 & 10 & 20 & 20 & 30 \\
\hline IV $16-20 \mathrm{~m}$ & 180 & 20 & 20 & 50 & 90 \\
\hline $\mathrm{V} 30-34 \mathrm{~m}$ & 80 & 260 & 70 & 80 & 30 \\
\hline
\end{tabular}

These molluscs which consisted of Limacina and larval gastropods occurred mostly in the deeper layers, and exhibited no marked diurnal movements.

CHORDATA.

\section{HEIMICHORDATA.}

\section{TORNARIA LARVÆ (Figure 2).}

$\begin{array}{cccccc} & \text { 1st Series. } & \text { 2nd Series. } & \text { 3rd Series. } & \text { 4th Series. } & \text { 5th Series. } \\ & 3.25 \text { pm.. to } & 7.55 \text { p.m.to } & 10.50 \text { p.m.to } & 2.50 \text { a.m. to } & 8.45 \text { a.m. to } \\ & 4.45 \text { p.m. } & 9.17 \text { p.m. } & 12.20 \text { a.m. } & 4.16 \text { a.m. } & 10.11 \text { a.m. } \\ \text { Surface } & 11 & 1153 & 14,840 & 563 & - \\ & 0 \cdot 4 \% & 29 \cdot 1 \% & 59 \cdot 1 \% & 9 \cdot 3 \% & 0 \cdot 0 \% \\ \text { II } & 581 & 1740 & 2580 & 1682 & 20 \\ \text { 2-7 m. } & 22 \cdot 7 \% & 43 \cdot 9 \% & 10 \cdot 3 \% & 2 \% \cdot 6 \% & 5 \cdot 4 \% \\ \text { III } & 887 & 120 & 1320 & 1920 & 160 \\ \text { 9-15 m. } & 34 \cdot 6 \% & 3 \% & 5 \cdot 3 \% & 31 \cdot 6 \% & 43 \cdot 2 \% \\ \text { IV } & 820 & 280 & 3890 & 840 & 120 \\ \text { 16-20 m. } & 32 \cdot 1 \% & 7 \cdot 1 \% & 15 \cdot 5 \% & 13 \cdot 8 \% & 32 \cdot 4 \% \\ \text { V } & 260 & 670 & 2469 & 1080 & 70 \\ 30-34 \mathrm{~m} . & 10 \cdot 2 \% & 16 \cdot 9 \% & 9 \cdot 8 \% & 17 \cdot \% \% & 19 \%\end{array}$

It would appear that these larvæ show a definite migration to the surface at midnight.

In the daytime the majority were taken between 7 and 20 metres: by 9 p.m. most individuals were above 7 metres, and at midnight they were concentrated right on the surface. By 4 a.m. they were leaving the 
actual surface, but were still caught in large numbers below a depth of 2 metres (Fig. 2).

The occurrence of this larva in such large numbers is worthy of mention. On this occasion we were evidently passing through a large shoal probably reaching the centre at midnight, when the numbers caught on the surface were as great as 14,000 .

\section{VERTEBRATA.}

\section{PISCES.}

All the young stages of Teleostean Fishes have been picked out, and will be dealt with in another paper on the vertical distribution of young fishes.

\section{SUMMARY.}

1. A series of hauls with the ring-trawl were made at five depths in water 50 metres deep, so that samples were obtained approximately in daylight, at dusk, at midnight, at dawn, and again in daylight.

A depth-recorder was used with the net giving a graphic record of its path through the water.

2. Examination of the catches demonstrated the diurnal changes in vertical distribution of the species caught by the ring-trawl.

3. Four types of behaviour were shown :-

(a) A definite migration to the surface in the dark hours of certain forms living in the deeper layers in the daytime.

(b) An expanding of the distribution of other organisms, that in the daytime had a zone of maximum abundance in the deeper layers, so that they were evenly scattered from the surface downwards.

(c) Certain animals showed no or v ry little change in their vertical distribution during the dark hours.

(d) A movement up to the midwater region by those forms that during the daytime adopt either a truly benthic existence or are congregated in the water layers immediately adjacent to the sea floor.

(Lists of species grouped under their respective types of behaviour are to be found on page 780 .)

4. Many such observations are required before conclusions can be drawn as to the normal diurnal behaviour of plankton animals: this is a definite record of what occurred in this locality in mid-July at a period of full moon in fair weather. 


\section{LTTERATURE.}

1. Atkins, W. R. G. Seasonal Changes in the Phosphate Content of Sea Water in relation to the growth of the Algal Plankton during 1923-1924. Journ. Mar. Biol. Assoc., N.S., Vol. XIII, No. 3, p. 701.1925.

2. Esterly, C. O.' The occurrence and vertical distribution of the Copepoda of the San Diego region. Univ. Cal. Pub. Zool., Berkeley, Vol. IX, No. 6, pp. 253-340. 1912.

3. Farran, G. P. Bulletin Planktonique, Pt. Il, p. 84. 1911.

4. Gough, L. H. Report on the Plankton of the English Channel in 1903. Mar. Biol. Assoc. Intern. Fish. Invest., 1902-1903. Southern Area. 1905.

5. Gurney, R. The larval stages of Processa canaliculata Leach. Journ. Mar. Biol. Assoc. N.S., Vol. XIII, No. 1, p. 263.1923.

6. Harvey, H. W. Hydrography of the English Channel. Cons. Perm. Int. pour l'Explor. de la Mer. Rapport Atlantique. 1924. (In Press.)

7. Herdman, W. A., And Scott, A. The Marine Biological Station at Port Erin. Proc. Trans. Liverpool Biol. Soc., Vol. XXII, p. 66. 1908.

8. Herdman, W. A., And Scott, A. An Intensive Study of the Marine Plankton around the South End of the Isle of Man. Pt. II., ibid., Vol. XXITI, p. 323. 1909.

9. Herdman, W. A., And Scott, A. Ibid., Pt. V, Vol. XXVI, p. 217. 1912.

10. Jackson, H. G. Eupagurus. L.M.B.C. Memoirs, No. XXI, Proc. Trans. Liverpool Biol. Soc., Vol. XXVII, p. 553. 1913.

11. Lebour, M. V. Young Anglers in Captivity and some of their Enemies. Journ. Mar. Biol. Assoc., N.S., Vol. XIII, No. 3, p. 730.1925 .

12. Mayer, A. G. Medusæ of the World, Vol. II. The Hydromedusæ, p. 491.

13. Michaet, E. L. Classification and Vertical Distribution of the Chætognatha of the San Diego Region. Univ. Cal. Pub. Zool., Berkeley, Vol. VIII, No. 3, pp. 21-186. 1911.

14. Russeld, F. S. Depth Recording with Plankton Nets. Nature, Vol. 115, No. 2895, pp. 603-604. April 25th, 1925.

15. SARs, G. O. An account of the Crustacea of Norway, Vol. III, Cumacea, p. 8. 1900.

16. Sсотт, T. Bulletin Planktonique, Pt. II, p. 122. 1911.

17. Stephensen, K. Hyperiidea-Amphipoda (Part 2). Rep. Danish Ocean. Exp., 1908-1910, No. 8, Vol. II (Biology), D 4, p. 101. 1924 . 